\title{
Trace Elemental Analysis in Epileptic Children
}

\author{
S. Kumar', V. Kumar', Reena Mittal'², D. C. Jain ${ }^{3}$ \\ ${ }^{1}$ Department of Physics, Medical Physics Research Laboratory, D.A.V. (P.G.) College, Muzaffar Nagar, India \\ ${ }^{2}$ Department of Mathematics, Shri K.K. Jain College, Muzaffar Nagar, India \\ ${ }^{3}$ Department of Neurology, Safdarganj Hospital, New Delhi, India \\ Email: sanjeev1962kumar@yahoo.co.in, sanjeev1962kumar@rediffmail.com,v_05kumar@rediffmail.com, \\ reena_math@rediffmail.com,neuro_dc@hotmail.com \\ Received March 30, 2013; revised May 2, 2013; accepted May 10, 2013
}

Copyright (C) 2013 S. Kumar et al. This is an open access article distributed under the Creative Commons Attribution License, which permits unrestricted use, distribution, and reproduction in any medium, provided the original work is properly cited. In accordance of the Creative Commons Attribution License all Copyrights (C) 2013 are reserved for SCIRP and the owner of the intellectual property S. Kumar et al. All Copyright (C) 2013 are guarded by law and by SCIRP as a guardian.

\begin{abstract}
We have measured trace elements in epileptic patients. Levels of trace elements are very fluctuating in comparison to the healthy controls. The levels of $\mathrm{Zn}, \mathrm{Fe}$ and $\mathrm{Cu}$ are higher in comparison to healthy normal children about $64 \%, 55 \%$ and $33 \%$ respectively. The levels of $\mathrm{Cu}$ are just fifty percent to levels of $\mathrm{Zn}$. The levels of $\mathrm{Ca}, \mathrm{K}$ and $\mathrm{Mg}$ are higher about $10 \%, 9.027 \%$ and $4.2 \%$ in comparison to normal children. Sodium levels were very low in comparison to all the trace elements and are higher about 3.2\% than controls. The multiple correlation coefficients between $\mathrm{Na}, \mathrm{K}$ and $\mathrm{Ca}$, i.e. $\left(\mathrm{R}_{\mathrm{Na} . \mathrm{KCa}}\right)$ has a value 0.4993 in comparison to healthy children. Multiple correlation coefficients between $\mathrm{Fe}, \mathrm{Cu}$ and $\mathrm{Zn}$, i.e. $\left(\mathrm{R}_{\mathrm{Fe} . \mathrm{CuZn}}\right)$ has a value 0.4366 . The multiple correlation coefficients $\mathrm{R}_{\mathrm{Na} \text {.KCa }}$ and $\mathrm{R}_{\mathrm{Fe} \text {.CuZn }}$ are found lower. These elements were strongly correlated with other. The multiple correlation coefficients such as $R_{\text {K.NaCa }}, R_{\text {Ca.K.Na }}$, $\mathrm{R}_{\mathrm{Mg} . \mathrm{NaK}}, \mathrm{R}_{\mathrm{Na} . \mathrm{MgK}}, \mathrm{R}_{\mathrm{K} . \mathrm{MgNa}}, \mathrm{R}_{\mathrm{Cu} . \mathrm{FeZn}}$ and $\mathrm{R}_{\mathrm{Zn.FeCu}}$ were also evaluated and found on higher side from normal range. Trace elements may act as a catalytic agent for enzyme system of the cells. The minimum requirements of living objects for essential trace elements may be expressed in proportions or concentrations of the total dry food taken everyday. A tolerance of the human system may be fluctuated according to intake of these elements.
\end{abstract}

Keywords: Flame Atomic Absorption Spectroscopy (FAAS); Grand-Mal Epilepsy (GME); Cerebrospinal Fluid (CSF); Central Nervous System (CNS) and Serum

\section{Introduction}

We know that minerals are important to our health. Minerals are inorganic chemical elements, which are not attached with carbon atom. It is very easy to differentiate between minerals and trace minerals. These trace minerals are called trace elements. If the human body accepts more than 100 milligram of 11 minerals each day, this substance is labeled a mineral. If the cellular body requires less than this requirement then it is labeled a trace mineral.

Trace minerals (elements) are needed in quantities of only a few milligrams or micrograms per day. Study of relationships of minerals with human health is important. If we balance the level of minerals in every organ, tissue and cell of the human body can be presumed that we are mintaining a good health.

Minerals comprise only a fraction of total bodyweight.
These are crucial for many body functions. These include transporting oxygen, normalizing the central nervous system (CNS) and simulating growth, maintenance and repair of tissues and bones [1].

It has been noticed that the regulation of trace elements balance in the body is essential to survival. Each cell is a living organism and we must try to maintain its internal environment. The movement of trace elements across cell membranes, between the extra-cellular and intra-cellular fluid forms the basis for the body's most primary functions. Electrical activity may be initiated; heart beats, nerve cells signal, muscles may respond, blood vessels may tighten or relax. Water balance should be maintained [2].

It has been reported in the literature that most of the trace elements found in the tissues and body fluids are also present in the blood [3]. Many of the metallic ele- 
ments have a specific metabolic function and the presence of these is not merely the result of contamination from our environment. Biologically active trace elements produce their effects through enzyme systems. Metalloenzymes and metal protein complexes are the two systems. Metalloenzymes have a fixed amount of specific metallic ion per molecule of protein addition of an agent, which binds the metal and inactivates the enzymes. Metal-protein complexes are larger group of proteins loosely bound to metal. Metals may substitute for each other with fluctuating degrees of affinity and they can be removed by the process of dialysis. Some of these complexes may have enzymatic activity only. Rests of these are concerned with transportation process only. Chelation affects these two types of activity of enzymes. The essential metals at trace levels play a role in the human body and can cause some diseases when present beyond the limit of normal concentration $[4,5]$.

Several minerals exist in living tissues in such small quantities that in the past, it was not possible to measure their precise concentrations with the analytical methods available at that time. That is why these elements were mentioned as occurring in traces and the term trace element was coined to describe such elements. The term has been in vogue, in spite of the fact that levels of almost all the trace elements can be measured with a very high degree of precision.

Trace elements occur in the tissue of animals, plants and micro-organisms in low concentrations. The concentrations of these elements change highly among many elements. Their concentrations are also different among various living organisms and their parts. These differences are also seen in nutritionally essential elements and also in those elements which are associated with no vital function.

Trace elements have divergent roles to play depending upon their chemical form or combination and their position in the body tissues and fluids. The functional forms of the trace elements and their characteristic concentrations ought to be maintained with narrow limits if the functional and structural integrity of the tissues is to be safeguard and the growth, health and fertility of the individual have to be unaffected. Continued ingestion of diets that are deficient, imbalanced, or excessively high in a particular trace element invariably induces changes in the functioning forms activities, or amount of these elements in the tissue or fluids, so that they fall below, or rise above the normal and permissible limits or ranges. In these situations, biochemical disturbances develop, physiological functions are influenced and structural disorders may arise in ways which change with elements. The degree and duration of the dietary deficiency or toxicity, age, sex and species are important factors associated with the trace elements [6].

\subsection{Deposition of Trace Elements in the Human Body}

Food is the basic necessity of life of a living organism. Everybody eats food whether it is vegetarian or nonvegetarian. Scientists were very curious about the food they consumed. Food passes in the body and affects the body. Food is the substance taken into the body that will help to meet the body's need for energy. It helps in maintaining good health, growth health, growth and reproduction.

A large number of minerals and trace elements are circulating in the human body. Some of these elements form part of body structural component and some others act as catalytic agents in different body reactions. Bones and skeleton are made up of calcium, magnesium and phosphorus and iron, which are components of blood. Minerals like zinc, molybdenum, copper, manganese and magnesium are either a structural part or activate a large number of enzyme systems. Iodine is a part of hormone, thyroxin. Sodium, potassium are important elements present in fluids within the outside the cells and along with ions like chloride, bicarbonate and carbonate keep water and acid base balance. If we see the case of growing infant and children, intake of additional amount of several minerals are essential to ensure adequate growth of tissues.

Every person absorbs minerals in a slightly different way, called biochemical individuality. Those nutrients that have not been transferred through the intestinal mucosal cell to enter the circulation have no meaning regarding the study of the elements. The variety of nutrients from organism's environment that have been made available by absorption must be transported through the circulatory system to the aqueous microenvironment of the cells. They may serve the purpose of participation in different metabolic processes in the cells on which the life of the total organism depends.

The absorption of minerals is dependent on many different factors related to the mechanism of human body. It has been reported somewhere in the literature that the addition of vitamins and minerals to food can be effective public health intervention to correct inadequate intake of nutrients in both the general society [7].

\subsection{Different Kinds of Trace Elements in the Human Body}

There are ninety two elements found in nature. We have some additional twenty two elements also. It has been reported in the literature that there are hundreds of isotopes of the elements exist. We may say the any one of which may play an undiscovered role in human health. We are presenting a table here to understand the exact percentage of the trace elements found in the nature as 
Table 1.

It has been established somewhere else in the literature that through geophysical forces, mixing of the earth's crust with water may provide virtually every mineral for our body, which requires to maintain health. The water is compatable with more substances that any other known solvent [8]. It is an ideal medium for transporting nutrients in the cells for the chemical reactions of cellular metabolism to take place.

Our body contains lots of elements out of 25 are divided into mainly three categories such as major, minor components and trace elements.

The major components which make up $96 \%$ of human body are composed of oxygen, nitrogen, carbon and hydrogen. It has been established that major elements found in the biological molecules such as proteins, nucleic acids, fats and carbohydrates and are capable to make-up the body. Hydrogen ions are very important for our cells to make ATP or energy. Water is also a medium for all the chemical reactions taken place in the human body. Water is a mixture of oxygen and hydrogen atoms [9].

Minor components make up $4 \%$ of our body. They may include calcium, phosphorus, potassium, sulfur, sodium, chlorine and magnesium. Some of these are necessary for chemical processes to run correctly. Our muscles need calcium in order to twitch properly. Enough calcium is required by body.

Table 1. Elements found in the earth's crust, ocean and atmosphere.

\begin{tabular}{|c|c|c|c|}
\hline S. No. & Type of element & Place where found & Percentage \\
\hline 1 & Oxygen & Earth crust & 46.50 \\
\hline 2 & Oxygen & Ocean & 85.79 \\
\hline 3 & Oxygen & Atmosphere & 20.95 \\
\hline 4 & Silica & Earth crust & 28.00 \\
\hline 5 & Aluminium & Earth crust & 8.10 \\
\hline 6 & Iron & Earth crust & 5.10 \\
\hline 7 & Calcium & Earth crust & 3.50 \\
\hline 8 & Sodium & Earth crust & 3.00 \\
\hline 9 & Sodium & Ocean & 1.14 \\
\hline 10 & Potassium & Earth crust & 2.50 \\
\hline 11 & Magnesium & Earth crust & 2.20 \\
\hline 12 & Magnesium & Ocean & 0.14 \\
\hline 13 & Titanium & Earth crust & 0.50 \\
\hline 14 & Chloride & Ocean & 2.07 \\
\hline 15 & Nitrogen & Atmosphere & 78.08 \\
\hline 16 & Argon & Atmosphere & 0.93 \\
\hline 17 & Carbon dioxide & Atmosphere & 3.03 \\
\hline 18 & Neon & Atmosphere & 0.0018 \\
\hline 19 & Helium & Atmosphere & 0.0005 \\
\hline 20 & Krypton & Atmosphere & 0.0001 \\
\hline 21 & Hydrogen & Ocean & 10.67 \\
\hline 22 & Hydrogen & Atmosphere & 0.00005 \\
\hline
\end{tabular}

Trace elements make up $0.1 \%$ of our body. They include copper, zinc, selenium, molybdenum, fluorine, iodine, manganese, cobalt, iron, lithium, strontium, aluminum, silicon, lead, vanadium, arsenic and bromine. These elements are necessary for our body to function properly.

Zumkley, H. [10] stated that clinical experimental and epidemiological studies indicate that a large number of trace elements may be involved in the etiology of different human body disorders. Both increased levels of any trace element or reverse of this can influence the development of disease.

\subsection{Effects of Trace Elements on Human Health and Why Do We Need to Get Analysis of Trace Elements}

To understand the effects of trace elements on human health is very complex in nature and fascinating. High concentrations of the elements may prove toxic. The depletion in the concentration of essential trace elements may cause so many different metabolic instabilities due to dysfunction of enzyme. Many metabolic changes in human body are accompanied by changes made in the concentration of one or more trace elements in some body fluids, such as blood serum or plasma.

It is very important to update ourselves with different techniques available for such type of determinations. Their operational aspects, advantages and disadvantages, etc. are important to understand also.

Trace elemental analysis from human hair, nails, body fluids such as plasma, serum and cerebrospinal fluid has been stated in the literature as the best predicator.

\subsection{Role of Trace Elements in Human Body with a Detailed Description}

Indian saint Swami Dayanand Saraswati quoted somewhere else in the literature "anything consumed in excess is poison”. By the beautiful quotation we can estimate our body in terms of trace elemental analysis and can assure the excess of one element may cause a diverse effect on the body. The role of trace elements may play an important role in human beings.

We may present a detail description regarding trace elemental effect on human body with an impact of deficiency of trace element may cause a serious disease. It is planned to discuss some of the trace elements in detailed and descriptive knowledge of few elements. These are copper, zinc, iron, magnesium, calcium, sodium and potassium. We are familiar with all these elements. We have a suitable position of these elements in the periodic table. We shall discuss each and every element in detail.

\subsubsection{Copper}

The presence of copper in animals and plants is very es- 
sential. Copper is most abundant trace element in human beings. This element is carried mostly in the bloodstream on a plasma protein. We may call it is ceruloplasmin. Copper is firstly absorbed in the gut and transported to the liver bound to albumin. This trace element is found in a variety of enzymes, including the copper centre of cytochrome $\mathrm{C}$ oxidase.

Our body needs copper for normal growth and health. It is said that copper is required to help the body use to iron. Copper is very important for nerve function, bone growth and to help body use sugar. This element is a component of a co-factor for different enzymes. Approximately, these enzymes are fifty in number and require copper to function properly.

It is an essential nutrient, which plays an important role in the production of haemoglobin, myelin, collagen and melanin. This element works with vitamin $\mathrm{C}$ also to help in making a component of connective tissues known as elastin. It is a critical functional component of a number of essential enzymes. These enzymes are cupro-enzymes. Copper is an essential component of the natural dark pigment and melanin. This melanin is needed to colour the skin, hair and eyes. The cupro-enzyme, tyrosinase, is required for the formation of pigment melanin. Melanin is formed in cells called melanocytes and plays a role in the pigmentation of hair, skin and eyes. This element is a strong antioxidant. It works together with an antioxidant enzyme, superoxide dismutase (SOD), to protect cell membranes from being destroyed by free radicals. Copper is needed to make adenosine triphosphate (ATP), which is required to run the body.

Copper may play a role in staving off heart, rhythm disorders and high blood pressure. The anti-inflammatory actions of the copper may help in reducing arthiritis symptoms. Many important oxidation reduction reactions in the body are catalyzed by copper. It helps the formation of water from the free hydrogen and oxygen present in the cells. The catalytic action of copper reduces the impact of this reaction. This reaction could be explosive if the copper is absent. The sense of taste, which is generated in the human tongue is influenced completely by the presence of copper. Copper must be available in sufficient amount in the human body to allow for the full utilization of iron. The absorption of iron into the body is stimulated by copper.

On an average, a young person requires one hundred to one hundred fifty milligram of copper daily. Copper in higher concentration is found in liver, hair, muscle and lung [11]. Absorbed copper is firstly attached to plasma albumin and then taken by the liver. It is released after the elapsed of time and bound to specific copper-carrying protein ceruloplasmin. Copper is an important component of so many metalloenzymes including cytochrome $\mathrm{C}$ oxidase. Copper absorption and retention depends on the chemical forms in which the metal is ingested, the dietary levels of other minerals and organic substances, and the acidity of the intestinal contents in the absorptive area. The mechanism of absorption of copper is not known and is still an open question.

Copper in the plasma is bound to serum albumin reversibly. It forms direct reacting pool of plasma. Copper and it is distributed widely to the tissues. The copperalbumin serum pool receives copper from tissues. Copper in ceruloplasmin does not appear to be so readily available for exchange or transfer. Small amount of fraction of serum copper is ultrafiltrable and consists of copper, i.e., free and another small fraction that is liganded to the amino acids.

The copper reaching the liver is incorporated into the mitochondria, microsomes, nuclei and soluble fraction of the parenchymall cells in proportions that vary with the age, the strain and copper status of human beings.

Only a small amount of copper approximately 10 to 60 $\mu \mathrm{g}$ is excreted in urine daily in human. Negligible amount of copper are lost in the process of sweat. During the menstrual cycle $0.5 \mathrm{mg}$ of copper may be lost in females. This loss may account for less than $0.02 \mathrm{mg} /$ day negative balance in females who are in their reproductive phase of life.

The adult human beings contain $80 \mathrm{mg}$ of copper. Newborn child has 4.7 part per million (ppm) and very young people contain more copper per unit of body weight than adults-approximately $1.7 \mathrm{ppm}$. A total of 23 $\mathrm{mg}$ in the liver, heart, spleen, kidneys, brain and blood of normal healthy subjects. Of this total, $8 \mathrm{mg}$ may present in the liver and surprisingly, $8 \mathrm{mg}$ in the brain. Highly variable concentration of copper occurs in the tissue of all human beings. The glands such as prostate, pituitory, thyroid and thymus are examples of tissues, which contain low copper; spleen, pancreas, muscles, skin, and bones contain intermediate concentrations of copper and the liver, brain, kidneys, heart and hair are tissues, which have high concentration of copper. It has been reported in the literature very specifically that variation of copper levels with age, the brain is the only organ in which the concentration increases from birth to about double the level at the age of maturity, i.e., 25 years. Exceptionally high concentration of copper occurs in the pigmented parts of the eye.

High liver copper concentrations are the indicator of a number of diseases of human beings. These diseases include thalasemia, hemochromatosis, cirrhosis and yellow atrophy of the liver, tuberculosis, carcinoma and severe chronic diseases accompanied by anemia, etc.

The copper in blood plasma occurs in two forms 1) firmly bound to cerlouplasmin and 2) reversibly bound to albumin. Plasma copper does not increase following meals or decrease during fasting. Serum copper levels 
increases in women who are taking oral contraceptives. Pregnant women have an elevated level of copper in comparison to healthy controls.

\subsubsection{Zinc}

The role of zinc in human subject as a nutritional point of view has been great importance to the research scientists in the field of Biophysics and Biochemistry for the past so many years. The importance has also established. Zinc is a necessary trace metal of suitable importance in the dietary management of many human body complex disorders. A young person has $3 \mathrm{gm}$ of zinc. A calculation shows that this is approximately half of the body iron, but ten to fifteen times greater than copper. This trace element is found in all our cells. This element is essential for all forms of life. Many proteins contain structures called zinc fingers may help to regulate genes. The distribution of zinc in human tissues is well documented in the literature. Liver, kidney, bone, retina, prostate and muscle appear to be very rich in zinc.

It has been reported in the literature that zinc in $\mathrm{RBC}$ is ten times that of plasma and in human serum is $16 \%$ higher than plasma. The higher content of zinc in serum has also been attributed to the liberation of zinc from the platelets during the process of clotting and to invisible hemolysis of red cells. The estimation of zinc in plasma of healthy controls has been studied by many scientists and found good in agreement. Plasma zinc levels in the new born child are in the same as in adults. The metalloenzyme carbonic anhydrase is a zinc containing enzyme. It is well documented that there are more than 80 other enzymes found, which possesses zinc including alkaline phosphate and alcohol dehydrogenease. The very high zinc content in the retina arises due to the metallo-enzyme retenene reductase, which sets up a relationship between the metabolism of vitamin A and zinc. Carbohydrate metabolism and DNA-synthesis require zinc. Most of the red cells zinc is tightly bound to enzyme carbonic anhydrase. It is exchangeable with plasma zinc. Whole of plasma zinc is found with proteins. Sixty percent zinc is bound to albumin, thirty percent is bound with alpha 2 macroglobulin and the remainder with low molecular weight proteins including amino acids [12].

The binding of zinc to amino acids and serum protein was studied by Prasad, A.S. et al. [13]. Histidine, glutamine, threonine, cystine and lysine showed the most markable effects. The amino-acid-bound fraction of zinc may have an important role in biological transport of zinc. The stable zinc content is higher in albumin fraction. Similar concentrations of zinc were found in the $\alpha-\beta$ and $\gamma$-globulins. These are fraction of immunoglobulin $\mathrm{G}$.

It is well established that zinc is a constituent of a number of metalloenzymes. Due to the property of colours, iron and copper enzymes have been recognized for some time. zinc metalloenzymes have emerged few years back. Kelin, D. et al. [14] have shown the first demonstration of a specific biological function critically dependent on the presence of zinc. They have also shown that carbonic anhydrase contains zinc and it is essential to the mechanism of action.

Riordan, J.F. et al. [15] have reported in the literature that there are more than seventy zinc metalloenzymes. Zinc metalloenzymes exhibit diversity both of catalytic function and of the role played by the metal atom.

Chemical stability may be an aspect of the utilization of zinc in diverse biological processes such as hydrolysis, transfer, and addition to double bonds and even oxidoreduction. Role of zinc in redox enzymes is not acceptable to donate or accept electrons.

A zinc metalloenzyme may be defined as a catalytically active metalloprotein containing stoichiometric amounts of zinc firmly bound at its active site. The metal atoms are so tightly bound that they do not dissociate from the protein during the isolation procedure. When the metal is not tightly bound, the association is chemically and functionally more tenuous and the destination metallo-enzyme are complex. The metal in zinc metalloenzymes participate in the actual catalytic process. One may speculate that the level of zinc in cells controls the physiological processes through the formation of regulation of activity, or both of zinc-dependint enzymes. Besides the bone and the intestine, the kidneys and stomach may also have reduced activity of alkaline phosphatase in zinc deficiency. In tissues such as blood, stomach and intestine in which carbonic anhydrase has a major functional role, reduced activities have been well established.

It is evident that zinc in small quantities is present in various cell membranes. Most of the membrane-bound zinc is linked to a distinct macromolecule constituent lipoprotein fraction.

The effect of zinc and other metals on aggregation of platelets and release of $\mathrm{H}^{3}$ serotonin activated either by collagen or epinephrine [16].

The interaction of zinc with calcium on the red cell membrane was discovered. The effect of manganese ion, which was shown to displace $\mathrm{Ca}^{++}$, thus modifying functions of the platelet membrane. Plasma zinc levels in the new born are in the same range as in the adults. It has been reported somewhere in the literature that the level of zinc falls to just below adult level within the first week of life. This continues till the next 90 days. This level reached finally to the adult level at the 4 months of age. At the age above sixty years, the plasma zinc values goes down. The use of predialyzed albumin, haptoglobin, ceruloplasmin, $\alpha$-macroglobulin, transferrin and IgG, incubated with $\mathrm{Zn}$, revealed that zinc was bound to all these proteins, and that the binding of zinc to $\operatorname{IgG}$ was electrostatic in nature. 
Only a small percentage of ingested dietary zinc is absorbed. Absorption is difficult to ascertain precisely, and intake-output studies are well documented. The nutritional status of zinc in infants and young children has been very limited.

In addition to vomiting, the symptoms of zinc toxicity in human beings may include dehydration, electrolyte imbalance, abdominal pain, nausea, lethargy, dizziness, and muscular in-coordination. If the person takes zinc chloride in suitable amount of dosage, the chances of renal failure may be ceased. The daily dosage of zinc in man is admissible from $15-30 \mathrm{mg}$. It is well established that zinc and copper compete with each other for similar protein binding sites. One thing is to be noted that one may induce copper compete with each other for similar protein binding sites. One thing is to be noted that one may induce copper deficiency in subjects receiving high amount of zinc for several months.

A syndrome of iron deficiency anaemia, hepatosplenomegaly and dwarfism has been found to be associated with malfunctioning of zinc metabolism [17]. Though this represents a human zinc deficiency syndrome, definite conclusions may be complicated because other nutritional deficiencies also exist in such type of patients.

Orthopaedic and central nervous system (CNS) have relatively slow zinc uptake. This element remains tightly attached for a lengthy span of time. The deficiency of zinc leads to growth retardation or failure, lesions of the skin and its appendages, and impaired reproductive development and function. Psychological disturbances are reported in individuals suffering from acrodermatitis en-teropathic [18]. Zinc induced deficiencies in human beings have been associated with neurological symptoms such as depression, poor concentration, nervousness and moodiness [19]. Deresti, I.F. et al. [20]. have studied the hippocampus, which is rich in zinc. Zinc deficiency is associated with learning and memory defects similar to behaviour syndromes resulting from destruction of the hippocampus. Acute oral zinc toxicity has been reported to produce drowsiness and somnolence.

\subsubsection{Iron}

This trace element is one of the first minor elements. It is essential for the growth of a child during the process of growing. Iron was considered to be celestial origin in ancient civilizations of the eastern mediterranean area. The metal of heaven was very much used in Egypt and Mesopotamia for therapeutic purposes.

Iron compounds were used by medical practitioners in the Greco-Roman period. Fairbanks, V.F. et al. [21] have reported that the therapeutic indications for iron during the Roman era included alopecia, acne, dermatitis, wounds, hemorrhoids, gout, pulmonary diseases, diarrhoea, vomiting, weakness, edema, fever and cystitis.
Many clinical disorders were shown to be associated with low serum iron. McCance et al. [22] have concluded from their research and have reported that once the iron was absorbed by the human body, its excretion was very minimal and was not controlled either by gastrointestinal tract or by the kidneys. The plasma iron was in equilibrium with tissue iron. The level of plasma iron influenced the rate of iron absorption. The intestine regulates the rate of iron absorption.

Radioactive iron was used in the year 1938 by the scientists to understand the metabolism of iron. Granick, S. [23] adopted and extended the hypothesis of ferritin as the mucosal regulator of iron absorption. This hypothesis was used and named as mucosal block theory. It was accepted as the physiological mechanism of regulation of iron absorption. According to this hypothesis, iron enters the mucosal cells and converted completely into ferritin iron. This ferritin iron is in equilibrium with small amounts of ferrous ions in the cells, and the ferrous ions combined with plasma $\mathrm{Fe}^{++}$and get an equilibrium state. If our body is depleted of iron and the plasma iron is found to be lowered, the iron from mucosa begins to move out into the blood stream. The physiological saturation of the mucosal cells with respect to ferrous iron is maintained until part or all of the ferritin iron is converted to ferrous iron. The depletion of iron leads to a fall in the ferrous iron below its saturation value in the mucosal cells, the radioactive iron administered orally begins to be absorbed. Iron is found in the hemoprotein enzymes, the cytochorme $\mathrm{C}$. The iron is concerned with oxidative mechanisms of all living cells. Moore, C.V. et al. [24] have pointed clearly to the plasma iron as the major form of transport iron. Flavoprotein enzymes of iron were discovered by Mahler, H.R. et al. [25] and Richert, D.A. et al. [26]. It is very well established by the researchers that the iron is intimately involved in oxygen utilization by the tissues as well as in oxygen transport as part of the hemoglobin molecule.

The liver and spleen contain the highest iron concentration. Kidneys, heart, skeletal muscles, pancreas and brain represent only one tenth of the concentration only in liver and spleen. The liver has a highest storage capacity of iron in man. Liver can store $10 \mathrm{~g}$ of iron in certain disease states. Iron occurs in blood as hemoglobin in the erythrocytes and as transferrin bound in the plasma. The ratio is 1000 to 1 . A little amount of non-heme iron is also found in the erythrocytes of human blood. Hemoglobin is a complex of globin and four ferroprotoporphyrin (heme) moieties. Fisher et al. [27] have synthesized this complex molecule.

Ingram et al. [28] have extablished a three-dimensional picture of molecule with its four attached hemes. They have studied the nature of the bond between iron and globin. Now iron is stabilized in the ferrous state 
completely, which allows it to be reversibly bonded to oxygen. Due to this mechanism, hemoglobin works as an oxygen carrier. The molecular weight of haemoglobin is approximately 65,000 . The average iron content is $0.34 \%$ of the hemoglobin.

The synthesis of heme and its attachment to the globin takes place in the advance stage of red cell development in the bone marrow. The production of these two parts occurs simultaneously.

The iron in human serum was studied by Holmberg, G.C. et al. [29]. The trace element iron may be bounded completely to transferrin. The statement was given by Schade et al. [30]. The amino-acid-bound fraction of iron may have an important physiological role in the biological transport of iron across cellular membranes. Some fraction about $30 \%-40 \%$ of the transferrin carries iron. Rest part of the transferrin is known as the latent ironbinding capacity. Sleep deprivation in human beings may be a factor to decline serum levels of iron. Most of fall in the iron level occurs during the first 48 hours of sleep deprivation. The serum iron levels may return to the normal value within a week.

It is well documented that ferritin and hemosiderin are two non haeme compounds. These occur in the tissues. The liver, spleen and bone marrow have a high concentration of iron. Both these compounds are not chemically similar. Ferritin is soluble in water but hemosiderin is insoluble. There is $20 \%$ of iron found in ferritin compound. It is of brown colour. Ferritin contains a central nucleus of iron surrounded by a shell of protein. The ferritin molecule is defined as a poly nuclear iron coated by assembly of protein chains. The average number of iron atoms per molecule of ferritin is 3000 or less. Ferritin has the storage capacity of 4500 iron atoms per molecule. The iron free apo ferritin consists of a shell $130 \times 10^{-10}$ $\mathrm{m}$ in outside diameter with a central cavity of $60 \times 10^{-10}$ $\mathrm{m}$ across. Serum ferritin is found higher in males in comparison to women. Many research scientists have established a correlation between serum feffitin, concentration and storage iron [31,32]. Hemosiderin is an amorphous compound. It has $35 \%$ of iron only. This type of the structure exists in the tissues as a brown, granular, readily stainable pigment.

The bone marrow and muscles contain suitable amount of non-haeme iron. The storage iron concentration of bone-marrow in normal man is $100 \mu \mathrm{g} / \mathrm{g}$. The non-haeme iron in the muscle is very low. The total amount is high due to large muscle mass. The total storage of iron in muscle is equal is to that of liver. The average concentration of iron in human milk is $0-5 \mu \mathrm{g} / \mathrm{ml}$. The level of iron in colostrum is 3 - 5 times higher than that in milk. Iron occurs in milk in combination with protein. An iron-protein compound named ferrilactin is found in small concentrations. This can be isolated from human milk.

The absorption of iron may be affected by the age, iron status, and the state of health. This absorption in man takes place mainly in the duodenum in the form of ferrous.

Iron occurs in foods in inorganic forms, in combination with protein, in heme compounds as a constituent of hemoglobin and myoglobin, and in other inorganic complexes. Iron in heme compounds is absorbed directly into the mucosal cells of the intestine without the necessity of release from its bound form. The inorganic forms of iron and the iron protein compounds need to be reduced to the ferrous state and released from conjugation for effective absorption. Amino acids such as histidine and lysine may help in iron absorption. It has been established that a direct reaction between iron and histidine occurs. They formed a chelate and subsequently absorbed. Histidine is a product of protein hydrolysis in the gastrointestinal tract. Amino acid may be involved in the normal absorption of iron.

High intake of zinc, cadmium, copper and manganese also interfere with iron absorption. During pregnancy, the lady lost 350 - $400 \mathrm{mg}$ iron in fetus and its adnexa. Although the absorption of iron may be increased during pregnancy in the third trimester of pregnancy. Hemoglobin levels go down.

The only way significant amount of iron are lost from the body is by blood loss. In case of women who are in the menstruation age group, the loss of iron is likely to be more than the dietary intake. Loss of iron is a reason of iron deficiency in women due to menstruation. Deficiency of iron may originate from insufficient input, inadequate absorption or too much loss by the bleeding. Inadequate food input is more usual compared to what is normally believed, specially in the aged persons as a growing hyochromic microcytic anaemia.

In normal situations, the absorption of iron is accurately regulated according to the requirements of the body. If a person consumes alcohol in excess, the absorption of iron becomes excessive. Haemochromotosis is a disease involving the storage of iron. This may be treated as the inborn defect in the metabolism. The iron deposited in the tissues damages progressively. The main organs involved by this mechanism are the liver cirrhosis, the heart which involved in the cardiac arrest and the pancreas for diabetes.

Serum iron can be estimated by the dilution of plasma. But the probability of iron contamination due to presence on non-visible hemolysis puts this method as highly unreliable. Data indicate that $50 \%$ increase can occur from non-visible hemoglobin and more than $100 \%$ from serum showing slight haemolysis.

In children anorexia, depressed growth and decreased resistance to infection but the oral lesions and nail 
charges are not so common. Significant fall in the iron content is a phenomenon commonly observed. In adults and post menopausal women the principal cause is chronic blood loss due to infections, malignancy, bleeding ulcers and hookworm infestation. Iron deficiency anaemia is more common in females compared to males. It is because women of fertile age are subject to additional iron losses in menstruation, pregnancy and lactation. Iron is necessary for red blood cells formation and function. The amount of iron needed is higher in women of child bearing age, which is important for brain function.

\subsubsection{Magnesium}

Magnesium is one of the best plentiful element on the universe with special reference to earth. This element is the fourth most abundant cation in the vertebrate. Aikawa, J.K. [33,34] showed in the studies related to magnesium and found that magnesium is associated with so many different biological processes.

Magnesium is present in a small concentration in all cells and it is necessary for cellular metabolism. This trace element is also present in bone along with calcium. It shares so many properties of calcium so far as absorption and metabolism and tissue distribution are concerned. This trace element is also implicated to have a role in cardiovascular disease. Magnesium is essential for certain enzymes. It protects mitochondria, which is the storehouse of energy from the dangerous oxidants.

Widdson et al. [35] have studied the magnesium content in human body and found a range of magnesium, which stated from 22.7 to $35.0 \mathrm{meq} / \mathrm{kg}$ weight of tissues. Magnesium reaches us in many forms. These are magnesium amino acidchelate, magnesium carbonate, magnesium oxide, magnesium oxide dolomite and magnesium sulfate. There is $70 \%$ of human body magnesium redides in bones and teeth. This element is essential to the functioning of human body. Because it transmits nerve impulses, causes the contraction of muscles and integral to healthy development of bones and teeth.

All the chemical reactions in human body require an enzyme system to help biochemical reaction mechanism. The enzyme system has three parts. They are protein molecule, which must be specific, another smaller organic compound called vitamin, such as pyridoxine or vitamin B6 and at the last a charged mineral, such as zinc, copper, manganese or magnesium. This element plays an important role of cofactor in more than 300 enzymatic reactions in the human body. Each mineral when dissolved in fluids has a characteristic electrical charge, which is called as valance. Minerals with a charge of + called univalent cations, include sodium and potassium. Minerals with a charge of ++ called divalent cations, include copper, zinc, manganese and magnesium. Potas- sium and magnesium are the most abundant cations found within the cells of the body with magnesium. One readily accessible and easily absorbed form of magnesium is magnesium chloride. It is soluble in water. This readily dissociates which can increase the rate of absorption. All the organic matter such as plants, animals and human body are made up of combination of elements such as oxygen, carbon and hydrogen. These tiny building blocks join to create the compounds that help in making our tissues, body fluids. Microscopic elements are used to regulate the body's function.

Magnesium is an important mineral that is needed by every cell in human body. It has been found that half of the magnesium stores in the body is deposited in the cells of the body's organs and tissues and rest half of this element is found in our bones. Magnesium occurs here in combination with phosphorus with phosphorus and calcium. It is well established that magnesium occurs only in one percent concentration in the blood. The human body has to work very hard in order to keep magnesium levels as constant in the blood. The human body contains about $760 \mathrm{mg}$ of magnesium at the ime of birth. It goes upto $5 \mathrm{gm}$ at the age of 4-5months and it reaches upto 25 $\mathrm{g}$ when a body attains an age of adult. About 30 to $40 \%$ magnesium is found in muscles and soft tissues. One percent is found in extracellular fluid, and the remainder is in skeleton. If we are going to consider the particular importance with respect to the pathological effects of magnesium depletion. We have to take into account the role of this element in regulating potassium fluxes and its involvement in the metabolism of calcium [36-38]. It has been established that magnesium depletion depresses both cellular and extracellular potassium and exacerbates the effects of low potassium diets on cellular potassium content. Muscle potassium depletes as magnesium deficiency develops, and tissue repletion of potassium is virtually impossible unless magnesium status is restored to normalcy. Low plasma calcium develops frequently as magnesium status declines. About $55 \%$ of body magnesium is located within bone, and it forms a surface constituent of the hydroxyapatite (calcium phosphate) mineral component. The magnesium is exchangeable with serum and therefore represents a moderately accessible magnesium store, which can be drawn on in times of deficiency. The proportion of bone magnesium in this exchangeable form declines significantly with growing age. It has been seen that there is a significant increase in bone mineral density (BMD) of the femur and is associated with the increase in erythrocyte magnesium. The other roles of magnesium in skeletal tissues are not widely known.

Magnesium is a miracle trace element. This element has a tendency of healing effect. Due to this property a wide range of diseases may reduce or disappear com- 
pletely. This trace metal has an ability to rejuvenate the ageing body. Magnesium is helpful in the development of healthy brain and nervous system. The teeth and bones may get the proper dosage of magnesium. Magnesium helps in the fight of the human body with infection.

One of the medical investigators has cured several patients of diphtheria with the dosage of magnesium chloride. The administration of this dosage was for two days only. Poliomyelitis cases were also studied and treated with the magnesium. The patients became fit within the couple of days. If the paralysis had already progressed the patients may got recovery within a month. It has been found that magnesium chloride is effective with asthma, bronchitis, pneumonia and emphysema, pharyngitis, tonsillitis, hoarseness, common cold, influenza, whoofing cough, measles, rubella, mumps, scarlet fever, poisoning, gastro-enteritis, boils, abscesses, whitlow, infected wounds and osteomyelitis. Many researchers have confirmed the healing effect of this of this salt magnesium chloride $\left(\mathrm{MgCl}_{2}\right)$ of magnesium in the diseases such as acute asthma attack, shock, tetanus, herpes zoster, acute and chronic conjunctivitis, optic neuritis, rheumatic disease, many allergic diseases, chronic fatigue syndrome. It was a beneficial effect in human health.

It has been found that young women, children and most of all babies have soft body structures and smooth skin with low calcium and high magnesium levels in cells and soft tissues. There is a remarkable finding in the literture available and we may be able to say that as the age grow old men and post menopausal women become more and more inflexible. The arteries harden to cause artheriosclerosis, the skeletal system calcifies to cause rigidity with fusion of the spine and joints, kidneys and other organs and glands increasingly calcify and harden with stone formation, calcification in the eyes causes cataracts and even the skin hardens, becoming tough and wrinkled. Now we can say that calcium is in the same scale (league) as oxygen and other free radicals, while magnesium works together with hydrogen and antioxidants to keep our body structure soft. Magnesium plays a major role in the functioning of the organs present in the human system. It helps in maintaining nerve and muscle functions, strengthens the immune system and maintains a steady heart rate. This element also helps to the regulate sugar levels in blood, plays a major role in protein synthesis and energy metabolism and maintains normal blood pressure. It prevents disorder like hypertension, diabetes and cardiovascular disease.

About $1 \%$ of magnesium is found in the extracellular fluid, inside cells, magnesium may be found bound to phospholipids. It is very important to note that increasing dietary protein intake may increase magnesium requirements because high protein intake may decline magne- sium retention [39].

It is advisable that to completely understand magnesium function, it is very important to explore magnesium's relationship with calcium and potassium. Magnesium and Potassium also have a close relationship. Magnesium is required for the function of sodium and potassium pump. If a magnesium deficiency occurs, then pumping of sodium out of the cell and pumping potassium into the cell may be impaired [39]. Cardiac attack comes due to the deficiency of magnesium. Magnesium plays a very important role of trace element in the cardiac function. The level of magnesium may cause severe problems. Many studies [40-43] have shown an effect of the level of magnesium regarding heart attack.

Alcoholism, renal disease, diabetes mellitus may all cause a deficiency of magnesium. Nausea, vomiting, anorexia, muscle weakness, muscle weakness, muscle spasms and tremors are the few symptoms and signs related to deficiency of magnesium.

Magnesium has an effect on CNS. It is used for a better sleep. This element may be used to calm irritated and over excited nerves. This is useful with epileptic attacks, convulsions in pregnant women and shakes with tremors in alocholism. If the level of magnesium is very low, the nerves lose control over muscle activity, respiration and mental processes. Nervous fatigue, ties and twitches, termers irritability, hypersensitivity, muscle spasms, restlessness, anxiety, confusion, disorientation and irregular heartbeat all respond to higher levels of magnesium.

Epilepsy is marked by abnormally low magnesium levels in the blood, spinal fluid and brain, causing hyperexcitability in regions of brain. It has been established that there is a sudden change in the progress of improving or disappearing of epileptic attack with the administration of proper dosage of magnesium. If the level of magnesium is low, the severity of epileptic attack goes up. Research scientist have made the studies on magnesium and found that this element works best in combination with vitamin B6 and zinc. Magnesium inhibits convulsions by limiting or slowing the spread of the electric discharge from an isolated group of brain cells to the rest of the brain.

\subsubsection{Calcium}

We know that $99 \%$ of calcium is found in the bones and teeth of a human body. Rest of the element resides in the soft tissues and blood of the body. Calcium is most important element of the body. Our body structure is made up calcium and other minerals. If the calcium is absent, we are not in a position to make a regular form or structure. We shall lie on the ground and not able to stand.

Calcium is the most important mineral in the human body. It has been measured and found that the average adult body contains in total $1 \mathrm{~kg}$ and ninty nine percent in 
the skeleton in the form of calcium phosphate salt. Extracellular fluid contains $22.5 \mathrm{~m}$ mol. We found this element about $9 \mathrm{~m} \mathrm{~mol}$ in the serum. About $500 \mathrm{mmol}$ of calcium is exchanged between extracellular fluid and bone. It is an essential element for all living things. It can be used for fertilization of cell and division of cells. This element is used for hormonal activities. Calcium also controls the mechanical stability of the walls and membranes in the cells and stimulates muscle contractions.

It has been reported in the literature that bones are the best reserve of calcium. Mineralization of teeth and bones is the main function of calcium. Mainly $99 \%$ of total body calcium is used the above mentioned process. Small amount of the rest body calcium is essential for the function of so many tissues such as clotting of blood, stimulation of secretory activity in all endocrine, exocrine, and neurocrine cells; and the regulation of contraction and relaxation in cardiac and skeletal muscle.

The skeleton is an important, chief reservoir of calcium. It serves to maintain both plasma calcium concentrations and to make optimal use of ingested calcium. Calcium serves both functions mainly by adjusting the factor of balance between the bone formation-transfer mineral from blood to bones, and bone resorption-transfer mineral from bone to blood.

Calcium is involved in the function of excitable tissues. Before the heart can beat, special cells in a region of the heart called sinoatrial mode (SA node) must spontaneously initiate an electric pulse. Calcium is mainly involved in the initialization the impulse the SA node. This impulse will stimulate the rest of the heart to contract. It is also involved in the contraction of heart muscles and muscles of the skeletal.

Contraction and expansion of blood vessels is performed by the utilization of calcium. Calcium is useful in the secretion of hormones and enzymes, as well as communication between the different sections of the CNS.

Bones are always a part of a continuous process of breaking down and reconstruction. This mechanism of breaking and building consists mainly of resorption and deposition of calcium into newly formed bone, with the end result bone formation. This process or balance of bone absorption and deposition begins to changes as the body attains a higher age. At this age break downs are high rather than building of bones. During the age of younger side more growth of bones starts with a less deterioration of the bones. In the case of women after the menopause the breaking of bones is high and less building of bones. Due to this process osteoporosis may develop. It helps in the formation of weak porous bones which is responsible for fracture of bones. If we supply a proper dosage of calcium in the human body then osteoporosis disease can be reduced and delayed.

Calcium shares left sided cell receptors and is essential for human health. It promotes blood clotting by activating the protein fibrin along with magnesium to regulate the heart beat, muscle tone, muscle contraction and nerve conduction.

Parathyroid hormone (PTH) which can be secreted by the parathyroid gland and calcitonin secreted by the thyroid gland can maintain serum calcium levels in the range 8.5 to 10.5 . Renal functions retain more calcium. This element plays an indispensable role in cell permeability, formation of bones and teeth, blood coagulation, transmission of nerve impulse and normal muscle contraction. Severe calcium imbalance requires emergency treatment because a deficiency called hypocalcemia can lead to tetany and seizures. Excess of calcium is responsible for cardiac arthythmias and coma

If the serum calcium levels go down, it can develop the problems related to failure of kidney and nerve fibre irritability and repetitive muscle spases, perioral parestheris, twitching, carpopedal spasm, tetany, seizures and cardiac arrest.

If the levels of calcium in serum are on the higher side, it causes hypercalcemia. Due to excess of calcium in the human body, it develops the muscle weakness, decreased muscle tone, lethargy, anorexia, constipation, nausea, vomiting, dehydration, polydipsia, and polyuria. If the calcium level goes upto $5.7 \mathrm{mEq} / \mathrm{L}$ it can work as a catalyst in the cardiac arrhythmias and coma.

Depression is mainly associated with hypercalcemia due to hyper-parathyroidism and hypervitaminosis D. Many patients suffering from hyperthyroidism receive diagnosis of psychoneurosis, schizophrenia or schizoid personality. Irritability, mood swings and paranoid psychosis are associated with hypocalcemia.

Emotional symptoms which occur due to disturbances of calcium homeostasis may be elevated with normalization of calcium metabolism. It has been established that a positive calcium balance may occur in skeleton as a whole for 10 to 15 years after cessation of linear growth.

In calcium homeostasis, the amount of calcium deposited in bone is the same as the amount reabsorbed. This disease develops at the age of 35 years. The deposition of calcium increases and occurs in proportion to bone growth, skeletal turnover, although less rapid during adulthood, in the growing child. This process continues throughout life upto fourth decade, i.e., 40 years. The turnover becomes dominated by bone resorption. It has been established that a positive calcium balance may occur in skeleton as a whole for 10 to 15 years after cessation of linear growth

It has been reported in the literature [44-47] that the ingested calcium mixes with digestive juice calcium in the proximal small intestine from where it is absorbed by a mechanism. This process has an active saturable component and diffusion componenet. Calcium is mainly 
absorbed by active transport during the low calcium intake. This active transport is called transcellular transport. If the intake of calcium is high, the increasing proportion of calcium many be absorbed by paracellular diffusion. The unabsorbed component appears in the faeces together with the unabsorbed component of digestive juice calcium. This is called as endogeneous faecal calcium. It is concluded that the faeces contain unabsorbed dietary calcium and unreabsorbed digestive juice calcium. Urinary and endogenous faecal calcium are not the only forms of calcium for excretion. The loss from skin, hair, and nails must taken into account. It is very well known fact that the deficiency of calcium causes osteoporosis. We are not in a position to say about bone and calcium metabolism during aging to enable calculation of the calcium necessities of older men and women. It has been found that calcium absorption decreases with the increase of age in both males and females [48-50]. The calcium content of the newborn baby is $24 \mathrm{~g}$. Maximum part of this calcium is laid down in the trimester of the pregnancy during which the fOetus retains $240 \mathrm{mg}$ of calcium daily.

The calcium content of human milk is $36 \mathrm{mg}$ per 100 $\mathrm{ml}$ [51]. A lactating lady may produce $750 \mathrm{ml}$ of milk daily. It has been reported that $280 \mathrm{mg}$ of calcium can be fed to a new born child. It is very interesting result, which is reported in the literature that the bone is lost during lactation and restored after weaning [52,53]. This type of loss of calcium can be prevented by the supplementation of calcium [54]. Calcium deficiency is dangerous. Researches have shown low bone density as a result of $\mathrm{Ca}$ deficiency. Due to low density, the fracture rate is very high in developing countries. Rickets has not been reported so far.

Calcium is a nutrient which plays a role in neuromuscular function, enzyme mediated mechanism, blood clotting and providing rigidity to the skeleton by virtue of its phosphate salts. Its non-structural roles require the strict maintenance of ionized calcium concentration in tissue fluids at the cost of skeleton.

Calcium requirements are essentially determined by the relationship between absorptive efficiency and excretory rate. The excretion may be started through bowl, kidneys, skin, hair and nails. The rate of calcium absorption from the gastrointestinal tract needs to match the rate of all losses from the body, if the skeleton is to be maintained at suitable value of calcium with extra input of calcium with water. It must be stored in non-oxidizing medium, such as a liquid hydrocarbon.

\subsubsection{Sodium}

Elemental sodium was isolated in 1807 by passing an electric current through molten sodium hydroxide. Elemental sodium not occur naturally on earth. The sodium quickly oxidizes in air and is reactive. The free metal is used for chemical synthesis, analysis and heat transfer applications. Sodium ion is soluble in water. It is present in great quantities on earth. Sodium ion is also a component of many minerals.

Before proceeding further, we wish to say something regarding electrolyte because chemically electrolyte are the substances ions in the solution. These ions acquire the capacity to conduct electricity. Human body contains electrolytes. The balance of the electrolytes is essential for function of cells and organs of human beings.

Main electrolytes which are measured in the blood by the doctors are sodium, potassium, chloride and bicarbonate.

Sodium is the positive ion $\left(\mathrm{Na}^{+}\right)$which is called cation. This is found in fluid outside the cells. Sodium is combined with the chloride make a common salt which is very necessary for the growth of human body. Excess of sodium is excreted in the urine. Sodium is very helpful in regulating the total amount of water in the body and the transmission of sodium into and out of the individual cells. It may also play a role in body functions. There are many processes in the human body such as in the brain, nervous system, and muscles. They require electrical signals for communication. The movement of sodium is very critical in the generation of electrical signals. Excess and deficit of sodium may lead to malfunction. The extreme value of sodium in the body can be fatal. Sodium is found in both states such as electrolyte and mineral. It helps in keeping water and the electrolyte balance in human body. Sodium is very essential to regulate nerves and muscles function.

Most of the sodium in the human body is found in blood and lymph fluid. Aldosterone hormone controlled partly the levels of sodium in human system. Adrenal glands are responsible for the hormone. The level of aldosterone in human body tells about the kidneys when to hold the sodium element in the body instead of passing it in urine. Small amounts of sodium may last through the skin during the process of sweating.

Sodium is an essential nutrient responsible for regulation of blood volume and blood pressure. Sodium maintains the complete balance of fluids in the human system. It transmits nerve impulses. The contraction of muscle and relaxation is influenced by the system [27]. This element maintains osmotic equilibrium and acid-base balance in the human body. The minimum physiological requirement for trace element sodium is $500 \mathrm{mg}$ per day. Healthy adult requires $1500 \mathrm{mg}$ of sodium per day.

It has been established in the literature that there is a counter balancing system. This system senses the volume. When the fluid retained, receptors in the heart and vessels which sense distension and pressure, cause production of arterial natriuretic peptide. This hormone acts in different ways to cause the body to lose sodium in urine. 
This causes the body's osmotic balance to drop, which in turn causes the osmoregulation system to excrete the excess water. The net (total effective) effect is to return the body's total fluid levels back to towards the normal value. Sodium cation is important in the neuron (brain and nerve) function.

The ability of the kidney to conserve sodium in response to sodium deprivation and to excrete sodium in response to sodium loading are impaired with the aging factor.

The sodium is a mineral, which regulates body fluid volume, concentration and acid-base mechanism. Sodium levels in human blood can drop whenever there is a disease that causes diarrhoea, vomiting or sweating. These symptoms lead to a loss of the body fluids and sodium also. The loss of sodium may be temporary and resolve when the illness disappears. It is very important mineral in human system which helps the body in proper nerve conduction, the passage of various nutrients into cells, and maintenance of blood pressure. If a person consumes too much or too little sodium, the intestines and kidneys respond to adjust the concentration to a normal value. The intestines absorb dietary sodium. Kidneys excrete a nearly equal amount of sodium into the urine.

The concentration of sodium in blood depends on the total amount of sodium and water in different arteries, veins and capillaries. Human body regulates sodium and water in many different ways. A sodium level in the blood is very low can cause seizures and coma. Very high intake of sodium may lead to death. Death is caused by heart failure. If the body has very low level of sodium, a disease called hyponatremia results. On the other hand, if we take more sodium salt, the hypernatremia may be the disease.

There are many diseases which are generated by the abnormal salt intake. These are diseases of kidney, pituitary gland, and hypothalamus. The hypothalamus and pituitary glands are also involved in the regulation of sodium by making and releasing vasopressin into the blood. The Vasopressin is known as anti-diuretic hormone.

Sodium levels may go up in unconscious patients because they do not consume more water. Water is continually lost by evaporation from the lungs in the urine. Excess of sodium is also dangerous can include confusion, coma, paralysis of lung muscles and death. The severity of the symptoms is related to how quickly the high sodium levels developed. If the levels build up suddenly, the brain cells can not adapt to their new high sodium environment. Moderately low levels of sodium may trigger fatigue, confusion, headache, muscle cramps and nausea.

If we are taking excessive sodium chloride (common salt, the chemical formula is $\mathrm{NaCl}$ ), heart attack will be a greatest problem. When the human body lacks exercise of work and carries out sitting jobs in the air conditioned room, there are few chances that the body will sweat out to excrete the unnecessary salts. When the process of excretion is blocked or stopped from one side and from the other side we are taking more salt, then the human system will collapse. Cardiac arrests and cramps around the cardiovascular area are quite imminent with the excess of salt.

Blood pressure in the body has to be maintained at the prescribed and standard rates. If the standards of the pressure are failed, the system leads to serious damage of the blood vessels and results might be lethal.

The excessive measure of blood pressure is a factor to give hypertension. If the cholesterol content in the body due to obesity combined with excessive consumption of sodium chloride, then hypertension occurs. It produces a restlessness in the patients. A tendency of hyperactivity of mood develops at all the time. A continuous stress develops and accumulates without our notice, due to lack of complete deep rest of our mind and our body.

Retardation of metabolism in the body is also a serious problem related to excessive intake of sodium chloride. Table salt is necessary for the growth of body but the consumption must be according to the need of body. Excess of salt due to the taste of the tongue must be very less. We should try to adjust accordingly.

\subsubsection{Potassium}

This element is very important for the proper function of all cells, tissues and organs in the human system. This is an electrolyte able to conduct electricity in the body, along with sodium, chloride, calcium and magnesium. It is very crucial element for proper heart function and plays an important role in skeletal and smooth muscle contraction, making it very useful for normal digestive and muscular function. This element acts as a conductor for energy impulses throughout the body. It triggers chemical reactions in the body. It is found inside the human body cells. It helps in smooth muscular and cellular functioning, cardiovascular functioning, muscle contractions, nerve transmission, in conversion of glucose into glycogen and muscle building, etc. It is necessary to monitor and regulate aldosterone (hormone). This element plays an important role of catalyst for many enzymes activities inside the human body. It helps in improving ATP hydrolysis. It is also termed as diuretic. It is easily absorbed by our body. It is believed that $85 \%$ $90 \%$ is excreted from our bowls and kidneys. Due to the alkaline property of this element, $\mathrm{pH}$ level is balanced and water level may get stabilized in the body. The main feature of potassium is to maintain blood pressure under control and helps in intra-cellular nutrient transfer. Po- 
tassium is also responsible for keeping acne, some types of allergies, fatigue, kidney stones, etc.

Potassium is eight most common elements by mass in the human beings. Studies show that an adult of weight approximately $60 \mathrm{~kg}$ has a potassium upto 20 grams. The human body has about as much potassium as sulfur and chlorine. Potassium cations are very important in the functions of neuron (brain and nerve). This element is also helpful in the osmotic balance between cells and intestinal fluid by $\mathrm{Na}^{+} / \mathrm{K}^{+}$AT phase pump. This ion pump uses ATP to pump three sodium ions out of the cell and two potassium ions into the cell creates an electrochemical gradient over the cell membrane.

Potassium can be detected by taste because this element triggers three of five types of taste sensation, according to concentration. It the dilution of potassium ion is present, then the taste will be sweet. Moderate percentage of potassium ion is found in milk and juices. Higher concentration becomes bitter or alkaline. If we have a highest level of concentration of potassium ion then the taste will be salty. This element is also important in preventing muscle contraction. It is being used in sending the all types of nerve impulses through action potentials. This element is necessary for the function of all living cells. Potassium ion diffusion is a key mechanism in nerve transmission, and potassium depletion in human. There are some neurological dysfunctions such as epilepsy, headache, migraine, muscular dystrophy and Alzheimer's Disease developed by the levels of potassium in the blood.

We would like to add here that below the normal value of potassium, we have a serious problem in the human body called hypokalemia. Potassium facilitates nerve impulse conduction and the contraction of skeletal and smooth muscles, including heart. It also facilitates cell membrane function and proper enzyme activity. The levels of potassium in the body must be kept in a suitable balancing condition for the maintenance of health.

1) Hyperkalemia:

If we found the levels of potassium in the blood higher than normal value then a disease may occur, which is called hyperkalemia. This may be related to an increase in total body potassium or the excess release of potassium from the cells into the blood stream. Kidneys remove excees potassium from the body. It has been found in most of the cases that hyperkalemia caused by disorders which reduce the ability to get rid of potassium. These disorders are such as acute kidney failure, chronic kidney failure, glomerulonephritis, obstructive uropathy and rejection of a kidney transplant.

Hypothyroidism is an illness of thyroid which may be a causative factor of potassium deficiency. It may be developed by the imbalance of other minerals similar to potassium such as magnesium, sodium and calcium.

It has been reported in the literature that there is a positive link between a diet rich in potassium and bone health. Suitable levels of potassium are the good sign of bone development in the human beings. Some studies related to blood pressure shows low levels of potassium. Supplement of this element might cause a slight drop in blood pressure. It has also been studied that if we are taking a diet rich in potassium, stroke risk is negligible otherwise it may be higher at any time, which is dangerous for our life. The hormone aldosterone regulates kidney removal of sodium and potassium. A deficiency of this hormone may be a cause of hyperkalemia. This deficiency increases the total body potassium. Addison's disease is one of the disorders that cause reduction of aldosterone.

Hyperkalemia may be caused by the medications. It has no symptoms but there are few signs such as irregular heartbeat, nausea, slow, weak or absent pulse related to this disease. This disease can have a serious life threatening effects on the human body. A gradual increase in potassium may occur with chronic renal failure. Potassium supplements can irritate the stomach and cause nausea. Higher levels of potassium in the blood will cause stomach cramps, diarrhea and disrupt the digestion process.

Muscle fatigue and weakness are the symptoms of too much potassium citrate. Numbness, tingling and limpness in the extremities are the side effects. These are the factors related with potassium.

2) Hypokalemia:

Hypokalemia means serum or plasma levels of potassium below the normal value. There are two causes for hypokalemia defined here one is related to overall depletion in body's potassium and the next is related to excessive uptake of potassium by the muscle from the surrounding fluids. It is well reported in the literature that need OF potassium IS to control muscle action. Hypokalemia can cause the heart to stop breathing.

Mild hypokalemia does not show any symptom understandable position is missing. If a person has moderate hypokalemia which is very important to diagnose easily by the help of some understandable symptoms such as confusion, disorientation, weakness and discomfort of muscles, discomfort in the legs. Severe hypokalemia may produce extreme weakness of the body, paralysis. Different types of paralysis such as flaccid, limpness, lung muscles are common. This type of hypokalemia may cause abnormal heart beat. Abnormal heart beat is dangerous for our heart and it is the sign of cardiac arrest. Hypokalemia does not show any symptom in healthy subjects because of the rich percentage of potassium is found in healthy persons. 


\subsection{Role of Trace Elements in Relation to Immunity}

Nutrition and health both are linked each other but the importance of trace elements on immune system is also a field of research, which was established in the last two decades. It is a field of understanding of adequate trace elements supplementation may be a good path to design a better nutrition, which protects human beings against infections.

Cell biology and molecular genetics are the branch of science have been facilitated main efforts to determine specific cellular and molecular functions of trace elements in maturation, activation and functions of host defense mechanisms.

Immune cells, require a proper supply of trace metals to express and preserve the structure and function metalloproteins. These cells may also participate in energy production. Trace element levels can effect the immune function not only in a direct process but also by modulating plasma levels of hormones which are used to regulate the development and function of host deference cells. The trace elements may influence some mechanisms of non specific immunity by modulating inflammatory cell function.

It has been seen that the effect of mineral deficiency on acquired immune system can be demonstrated by examining the response of lymphocytes to $\mathrm{T}$ cells mitogens. The levels of trace elements may also affects the synthesis and secretion of cytokines and chemokines which modulate the activities of immune and other cells.

A good application of micronutrient which are also called as trace elements interventions is probably related to vaccine response in older stage in human beings. Mortality associated with influenza is more likely to appear in this population.

A significant physiological role of many trace elements in the development, maturation, and sustenance of the morphologic integrity and function of the lymphoid organs concerned with immunity has been well established.

The immune system plays a key role in the body's ability to fight against infections and reduce the risk of developing tumors autoimmune and degenerative disease. Nutritional deficiencies and excesses influence different components of the immune system.

Katz, M. et al. [55] and Suskind, R.M. et al. [56] have studied the influence of nutrition upon host immune compertence. Correlations of protein and energy nutriture and their role in immuno responsiveness have been studied by Bongiorni, I.B. et al., [57] and Malave, I. et al. [58]. Many trace elements are critical for mammalian survival and reproduction. High consumption of highly refined and heavily processed food items reflect that the trace element content may be reduced significantly.
It has been established that the observations of marginal zinc status coupled with experimental examinations of altered immunocompetence and impaired response to pathogenic challenge in zinc-deficient. A significant appreciation for the essentiality of zinc for intact immunlological function has been created. It has been surveyed that the patients with low serum levels of zinc may increase the susceptibility to a variety of infections disorders as well as abnormal immune parameters. Cellular immune reponsiveness and responds to zinc administrations with nearly complete amelioration of their immunodeficiency syndrome.

A protein-energy malnourised children have been shown to have low levels of serum zinc, and the immuno deficiency syndrome may be observed in such patients can be partially corrected by zinc administration.

The value of level of zinc may affect the phagocytic cell function the complement system and mast cell mediator release which can be seen at the efferent arm of immune response [59].

Some of the studies on the role of copper metabolism and immune functions have been carried out and shown the effect on $\mathrm{T}$ and $\mathrm{B}$ cells, neutrophils, macrophages, as well as complement and immunoglobulin structure and function. Rigas et al. [60] reported that an additional process due to which copper acts in altering immune response may involve an interaction at the level of the plasma membrance. Copper has bean shown to ameliorate the toxic effects of diethyldithiocarbamate upon both $\mathrm{T}$ cell and polymorphonuclear leukocytes. The interaction of copper must occur at the cell membrance. Serum copper and cerroluplasmin levels increase in a large variety of acute infectious disorders.

Calcium ion are involved intimately in so many aspects of lymphocyte activation such as blast transformation in response to mitogens. Calcium is known to complete in a number of biological systems.

\subsection{Review of the Literature and Estimation of the Trace Elements in the Blood of the Patients Suffering from Epilepsy}

For the perfect maintenance of vital mechanisms of the organs, the three elements must be present within the specific ranges of concentrations. Trace elements should fulfill the special biological functions such as catalysis in the synthesis of proteins and enzymes, as active centres of proteins and as structure forming parts of molecules [61].

Blood serum and plasma are the body fluids can be investigated with respect to trace elements. How much amount of trace element enters into the blood circulation after absorption in the gastrointestinal tract depends on its chemical binding, which is available in the food stuff. Products of catabolism are also transported via the serum 
to be excreted or reutilized. Deficiency states become evident when the body pools are depleted at a point too late for prevention of the disease.

Adnan, M. et al. [62] have studied simultaneous determination of $\mathrm{Cd}, \mathrm{Pb}, \mathrm{Cu}, \mathrm{Zn}$ and $\mathrm{Se}$ in human blood of Jordanian smokers by ICP-OES and compared with those of healthy subjects and found that the average concentrations of $\mathrm{Cu}$ and Zinc were 2.328 and $3.214 \mathrm{mg} /$ litre respectively. Results revealed that the finding are in good agreement with the certified values.

Keck, E. et al. [63] have studied calcium metabolism and vitamin D metabolite levels in children receiving anticonvulsant drugs and found that their data do not support the hypothesis that anticonvulsant drugs act on vitamin D metabolism.

John H. et al. [64] have studied altered calcium metabolism in epileptic children on anticonvulsants. They have shown a reduction of serum calcium levels in thirty percent and a raised serum alkaline phosphate in twenty four percent. On the basis of statistical theory the inverse correlation with the level of serum calcium have been found. Serum calcium level were found $9.0 \mathrm{mg} / 100 \mathrm{ml}$, which is below the normal value.

William, B. H. et al. [65] have studied trace metals in human plasma and red blood cells and reported few findings, which are very useful for the diagnosis of the diseases such as the levels of magnesium in the plasma has a range 12.5 to $36.0 \mathrm{ppm}$. Copper has a range 0.50 to $1.93 \mathrm{ppm}$ and the levels of zinc have a range from 0.49 to $7.70 \mathrm{ppm}$. They have also used statistical analysis and found that the value of zinc were lowered.

Guidotti, T. L. et al. [66] have shown some of the findings on the interpretation of trace element analysis of body fluids. They have estimated copper levels in the serum and found that the levels are 11 to $28 \mu \mathrm{mol}$ per litre. The level of zinc were measured and found as 8 to $20 \mu \mathrm{mol} / \mathrm{litre}$.

Khanna R. S. et al. [67] have studied the role of trace elements and antioxidants in free radical medical injury in neonates. They have reported their findings for birth asphyxia and measured the elements such as zinc, copper and iron. The levels of zinc were found as $(99.523 \pm 7.44)$ $\mu \mathrm{g} / \mathrm{dl}$, copper levels were $(38.119 \pm 2.68) \mu \mathrm{g} / \mathrm{dl}$ and iron levels were reported as $(108.636 \pm 13.03) \mu \mathrm{g} / \mathrm{dl}$. They have also calculated and estimated the levels of trace elements and reported that the plasma zinc, copper and iron levels were elevated.

Walsh, W. J. et al. [68] have studied elevated blood copper/zinc ratios in assaultive young males. They have shown mean $\mathrm{Cu} / \mathrm{Zn}$ ratio in assaultive subjects as $1.40 \pm$ 0.54 and compared with healthy controls and found this ratio as $1.02 \pm 0.18$. It has been seen that the ratio is higher than normals, either the levels of copper or zinc were higher. We can safely say that assaultive person has a higher value of the ratio of $\mathrm{Cu} / \mathrm{Zn}$. One can make a check on this ratio to normalize it for the safe living of the young males to leave the nature of assault.

Pamela J. F. [69] has studied zinc deficiency and immune function and reported their findings as modest deficits in zinc cause lymophophenia and reduced immune capacity among affected human beings. Skin lesions and poor wound healing were also observed in severe forms of the deficiency of zinc.

Atilla, I. I. et al. [70] have studied the comparison of nail and serum trace elements in patients with epilepsy and healthy subjects and found that there were no significant difference in serum zinc levels between epileptic patients and normals. They have reported other findings related to copper levels in serum also. The levels of copper in serum were significantly higher in comparison to normals.

Smith J. C. et al. [71] have studied direct measurement of zinc in plasma by atomic absorption spectroscopy. They have shown low zinc values in plasma as $(70 \pm 0.0)$ $\mu \mathrm{g} / \mathrm{dl}$ whereas in controls it was found $(90 \pm 0.0) \mu \mathrm{g} / \mathrm{dl}$. The higher Zinc values were $(158 \pm 5.0) \mu \mathrm{g} / \mathrm{dl}$.

Prasad R. et al. [72] have studied cerebro-spinal fluid and serum zinc, copper, magnesium and calcium levels in children with idiopathic seizure. They have reported that high serum copper levels and increased ratio of $\mathrm{Cu} / \mathrm{Zn}$. Magnesium could be responsible for elevated neuronal excitement in children with idiopathic seizures. The serum copper levels were $(112.9 \pm 41.88) \mu \mathrm{g} / \mathrm{dl}$. The normal value were reported as $(66.46 \pm 18.44) \mu \mathrm{g} / \mathrm{dl}$. Serum zinc level were $(64.82 \pm 18.44) \mu \mathrm{g} / \mathrm{dl}$. These levels were decreased from the normal values. Serum magnesium levels were reported as $(0.87 \pm 0.34) \mu \mathrm{g} / \mathrm{dl}$ and compared to normal $(0.93 \pm 0.18) \mu \mathrm{g} / \mathrm{dl}$. These levels were below the normal value of. Serum calcium levels were found to be $(10.47 \pm 1.16) \mu \mathrm{g} / \mathrm{dl}$ and compared with normal $(10.76 \pm 3.29) \mu \mathrm{g} / \mathrm{dl}$. These were below the normal value but not significant.

Tinggi, U. et al. [73] have made their contribution related to trace metals and studied the trace metals using flame atomic absorption technique. It has been reported in their article as the levels of $\mathrm{Cu}$ were found to be $(61 \pm$ 5) $\mu \mathrm{g} / \mathrm{ml}$ and levels of zinc were measured as $(861 \pm 23)$ $\mu \mathrm{g} / \mathrm{ml}$.

Wills J. B. [74] has studied the levels of magnesium in blood serum and estimated these levels with the help of flame atomic absorption spectrophotometric technique. They have measured the levels of magnesium in the human blood with the removal of calcium from the serum.

Deniz T. et al. [75] have studied effects of antiepileptic drugs on serum and hair trace elements. They have reported their findings as the level of copper were found to be $(114.55 \pm 7.38) \mu \mathrm{g} / \mathrm{ml}$ and normals were reported as $(111.22 \pm 13.06) \mu \mathrm{g} / \mathrm{ml}$ for group A. Group B was also 
studied and the level of copper were reported as (111.45 $\pm 5.97) \mu \mathrm{g} / \mathrm{ml}$ and normals (112.65 \pm 9.35$) \mu \mathrm{g} / \mathrm{ml}$.

The levels of zinc were estimated in Group A as $(56.65 \pm 4.67) \mu \mathrm{g} / \mathrm{ml}$ and in controls $(99.0 \pm 8.0) \mu \mathrm{g} / \mathrm{ml}$. The estimation of zinc were carried out in group B also and found that the level of zinc were reported as $(69.75 \pm$ $3.07) \mu \mathrm{g} / \mathrm{ml}$ and in normals measured as $(85.90 \pm 2.79)$ $\mu \mathrm{g} / \mathrm{ml}$.

The levels of magnesium were also made and reported as $(130.5 \pm 7.9) \mu \mathrm{g} / \mathrm{ml}$ and in normals as $(134.0 \pm 9.41)$ $\mu \mathrm{g} / \mathrm{ml}$ in group A. Group B also conducted for the estimation of magnesium and reported as $(19.44 \pm 0.53)$ $\mu \mathrm{g} / \mathrm{ml}$ and in normal $(19.50 \pm 6.4) \mu \mathrm{g} / \mathrm{ml}$.

Soylak M. et al. [76] have studied copper and zinc concentrations of serum samples of healthy people living in Tokat, Turkey and they have reported the levels of zinc and copper as $(0.54 \pm 0.21) \mathrm{mg} / \mathrm{ml}$ and $(0.86 \pm 0.24)$ $\mathrm{mg} / \mathrm{ml}$ respectively. The mean concentration of zinc and copper were found in the lower limits of the worldwide acceptable values.

Lech, T. [77] has reported his findings on calcium and magnesium content in hair as a predictor of diseases in children. The levels of calcium were found in healthy children as $(906 \pm 796) \mu \mathrm{g} / \mathrm{g}$ and magnesium levels as $(29.4 \pm 32.9) \mu \mathrm{g} / \mathrm{g}$. The calcium levels in neurological diseases were also measured and found as $(520 \pm 436)$ $\mu \mathrm{g} / \mathrm{g}$ and the level of magnesium as $(29.3 \pm 25.3) \mu \mathrm{g} / \mathrm{g}$. Leh has shown the complete story of calcium and magnesium levels in the different age group of the children, which has a range from 0 to 15 years. He has also reported in the literature that the children with neurological disorders suffer from high deficiencies of calcium in their hair in relation to magnesium. Deficiency increases with the aging. A deficiency of magnesium in the body as a whole can appear for periods without the occurrence of hypomagnesemia. The low magnesium and calcium allow us to suppose that the deficiencies in calcium are caused by the deficit level of magnesium.

Avci, H. et al. [78] have studied trace elements in epileptic patients with special references to hair analysis and compared their results with the healthy subjects. They have measured copper, iron, zinc, magnesium and calcium with the application of spectroscopy such as flame atomic absorption spectrophotometric method. A detailed analysis for controls shown that the levels of copper were found to be $(19 \pm 7) \mu \mathrm{g} / \mathrm{g}$ in males, and $(16 \pm 8) \mu \mathrm{g} / \mathrm{g}$ in females. The levels of iron reported as $(9 \pm 2) \mu \mathrm{g} / \mathrm{g}$ in healthy males and $(15 \pm 9) \mu \mathrm{g} / \mathrm{g}$ for healthy females. Zinc levels were estimated for healthy males as $(200 \pm 61)$ $\mu \mathrm{g} / \mathrm{g}$ and $(218 \pm 87) \mu \mathrm{g} / \mathrm{g}$ for healthy females. It has been noticed that the levels for magnesium in healthy males were $(259 \pm 76) \mu \mathrm{g} / \mathrm{g}$ and $(505 \pm 219) \mu \mathrm{g} / \mathrm{g}$ for healthy females. The levels of calcium in healthy subject males only were $(960 \pm 419) \mu \mathrm{g} / \mathrm{g}$ and $(1162 \pm 533) \mu \mathrm{g} / \mathrm{g}$ for healthy females.

During the process of epileptic patient's analysis, the levels of copper in males were found as $(14 \pm 9) \mu \mathrm{g} / \mathrm{g}$ and in females as $(10 \pm 2) \mu \mathrm{g} / \mathrm{g}$. The levels of iron in males were reported as $(6 \pm 4) \mu \mathrm{g} / \mathrm{g}$ and in females these were $(7 \pm 5) \mu \mathrm{g} / \mathrm{g}$. Levels for zinc were also measured and found as $(211 \pm 63) \mu \mathrm{g} / \mathrm{g}$ in males and $(218 \pm 127) \mu \mathrm{g} / \mathrm{g}$ in females. The levels of magnesium in males were reported as $(329 \pm 285) \mu \mathrm{g} / \mathrm{g}$ and $(444 \pm 203) \mu \mathrm{g} / \mathrm{g}$ in females. Calcium levels were also measured and found to be $(947 \pm 850) \mu \mathrm{g} / \mathrm{g}$ in males, while $(1143 \pm 437) \mu \mathrm{g} / \mathrm{g}$ in females. They have reported that lower levels of iron and copper were observed and which were significantly lower in scalp hair analysis.

Delves H. T. et al. [79] have studied the concentration of trace metals in the blood of epileptic children and found that the levels of iron, zinc and copper in healthy controls as $(386.0 \pm 0) \mu \mathrm{g} / 100 \mathrm{ml},(510 \pm 0) \mu \mathrm{g} / 100 \mathrm{ml}$ and $(97.9 \pm 0) \mu \mathrm{g} / 100 \mathrm{ml}$. They have measured these levels in children of different age group as $(373.4 \pm 0)$ $\mu \mathrm{g} / 100 \mathrm{ml},(617.9 \pm 0) \mu \mathrm{g} / 100 \mathrm{ml}$ and $(102.2 \pm 0) \mu \mathrm{g} / 100$ $\mathrm{ml}$ respectively.

Smith, J. C. et al. [80] have studied the serum levels of zinc and copper in epilepsy and found that the levels of zinc in epilepsy $(13 \pm 2) \mathrm{mg} / \mathrm{dl}$ and in controls $(14 \pm 2)$ $\mathrm{mg} / \mathrm{dl}$. They have measured copper levels also and reported as $(18 \pm 3) \mathrm{mg} / \mathrm{dl}$ in epilepsy and $(18 \pm 6) \mathrm{mg} / \mathrm{dl}$ in healthy controls.

Kumar S. [81] studied zinc, copper and iron in Grand Mal (G.M.) epileptic patients and found the levels of zinc as $(38 \pm 16) \mathrm{mg} / \mathrm{dl}$ in controls and $(16 \pm 9) \mathrm{mg} / \mathrm{dl}$ in epilepsy. The levels of copper were also measured and found as $(44 \pm 24) \mathrm{mg} / \mathrm{dl}$ in controls and $(30 \pm 17) \mathrm{mg} / \mathrm{dl}$ in epilepsy. Iron levels were also estimated with the help of flame atomic absorption photometric technique and reported as $(20 \pm 8) \mathrm{mg} / \mathrm{dl}$ in controls and $(29 \pm 15)$ $\mathrm{mg} / \mathrm{dl}$ in epilepsy.

Kaji, M. et al. [82] have studied serum copper and zinc levels in epileptic children with valporic treatment and reported their findings as the levels of copper were significantly lower. The levels of copper were measured as $(82 \pm 16.6) \mu \mathrm{g} / \mathrm{dl}$ in epileptic patients and $(97.3 \pm 23.0)$ $\mu \mathrm{g} / \mathrm{dl}$ in normal healthy subjects. The levels of zinc were not altered in patients.

Barlow, P. J. et al. [83] have studied trace elemental abnormalities in hyperactive children and agitated senile dements and found that levels of zinc were significantly lower in hyperactive children. They presumed that there may be homeostatic mechanisms that maintain serum zinc relatively constant.

\section{Basic Theory of Flame Atomic Absorption Spectroscopy}

The phenomenon of atomic absorption was first observed 
in 1802. Walsh, A. proposed the atomic absorption spectroscopy for the quantitative analysis of elements [84]. Skoog, D.A. et al. [85] have supplied relevant informations about this technique in detail. Atomic absorption analysis involves measuring the absorption of light by vaporized ground state atoms and relating the absorption to concentration. The incident beam of light is attenuated by atomic vapour absorption according to Beer's Law. The instrumental and chemical parameters of the system must be geared towards the production of neutral ground state atoms of the proposed element for study. The conversion of sample from its native state to the atomic state can be achieved by using a method called flame atomic absorption spectroscopy (AAS) or an electric furnace. The sample undergoes a number of pretreatment steps prior to analysis in the furnace.

The sample is dried by evaporating the solvent in the first step. The organic matrix is decomposed by heating the sample in the second step. The heating temperature may go upto $1000^{\circ} \mathrm{C}$. Ultimately, the furnace is rapidly heated to a temperature around $2400^{\circ} \mathrm{C}$ to produce vaporized neutral atoms with as many as possible in their electronic ground states.

The absorption spectrum of the gas phase atoms is extremely narrow of the order $\leq 10^{-2} \mathrm{~nm}$. Thus the ligand source used for absorbance measurements must be exactly the correct wavelength and of narrow line width for Beer's law to remain valid. The light source used in AAS is a hollow cathode lamp in which light is emitted from excited atoms of the same element which is to be determined. This means that the radiant energy corresponds directly to the wavelength, which is absorbable by atomized sample. This method gives up both sensitivity and selectivity. Other elements in the sample will not generally absorb chosen wavelength and thus, will not interfere with the measurement. Molecular species may also be formed during the step of atomization. This can alter the spectral characteristics of the analyte metal or can cause spectral interference at the wavelength being monitered. To reduce background interference, the wavelength of interest is isolated by a monochromator placed between the sample and the detector. Zeeman or $\mathrm{D}_{2}$ techniques for background correction may also be used for complex matrices. We used a graphite furnace atomic absorption spectrophotometer. The ashing and atomization processes can also be examined. A calibration of this instrument has been made for different elements using a series of standard solutions.

AAS determines the presence of metal in liquid samples. It is an instrument to measure the concentration of metals in the sample. Metals will absorb ultraviolet light in their elemental form when they were excited by heat. Each metal has a characteristic wavelength of absorbance be absorbed. This spectrophotometer locks for a particu- lar metal by focusing a beam of ultraviolet light at a specific wavelength through a flame into a detector. The sample of interest aspirated into the flame. If the metal is present in the sample will absorb some of the light, which reduces the intensity. The instrument measures the change in intensity. The change in intensity may be converted into absorbance. If the concentration is made high, the absorbance will also rise.

It has been established in the literature that the AAS throw light and give informations regarding the number of gaseous metal atoms remain in the ground state normally. These ground state atoms are more capable of absorbing radiant energy of their own specific resonance wavelength. The light of resonance wavelength is passed through a flame containing the atoms, then some part of the light will be absorbed. The extent of absorption is proportional to the number of ground state atoms present in the flame. The atomic absorption spectroscopy is based on the same principle as the flame test used in qualitative analysis. In the flame, the ions are reduced to gaseous metal atoms.

$$
\text { Compound } \stackrel{\text { heated }}{\longrightarrow} \text { Atoms }
$$

The high temperature of the flame excites a valence electron to a higher energy orbital. The atom then emits energy in the form of visible light as the electron falls back into the lower energy orbital (ground state). Energy diagram for excited and emitted states is given in Figure 1.

The ground state atom absorbs light of the same characteristic wavelengths as it emits when coming back from the excited state to the ground state. The intensity of the absorbed light in proportional to the concentration of the element in the flame. Absorbance or emission of atomic vapour can be measured.

\subsection{Relationship between Absorbance and the Concentration of Atoms}

Integrated absorption may be calculated by the formula which is given below

$$
\int K_{v} \mathrm{~d} v=\left(\pi e^{2} / m c\right) f N_{0 v}
$$

Here, $K_{v}$ is absorption coefficient at the frequency $v ; e$ is electronic charge; $m$ is mass of an electron; $c$ is velocity of light; $f$ is oscillatory strength of the absorbing line; $N_{0}$ is number of metal atoms per $\mathrm{ml}$. able to absorb the radiation.

A graph between frequency and absorption coefficient is shown in Figure 2.

\subsection{Effect of Temperature on Atomic Spectra}

It has been established that the temperature changes number of atoms in ground and excited states.

Boltzmann has established a simple relation for the 


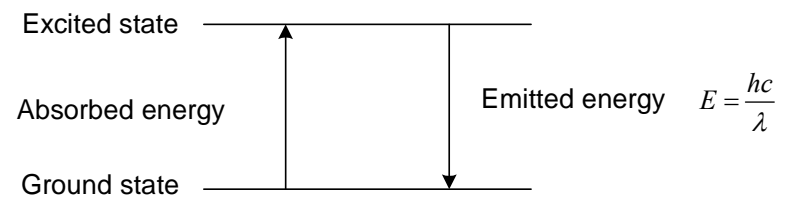

Figure 1. Energy diagram for the excited and emitted states.

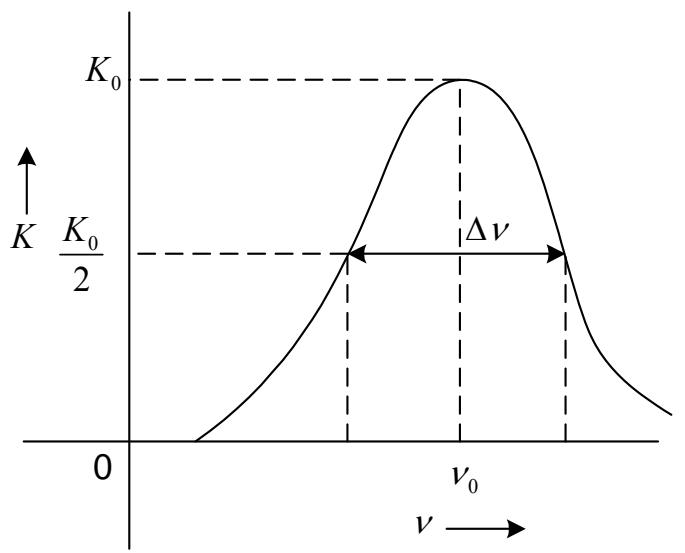

Figure 2. Graph between the absorption coefficient and frequency.

number of atoms as

$$
\frac{N_{1}}{N_{0}}=\frac{P_{1}}{P_{0}} e^{-(\Delta \in / k T)}
$$

Here

$N_{1}$ are number of atoms in excited state.

$N_{0}$ are number of atoms in the ground state.

$k$ is Boltzmann constant equal to the value $\left(1.28 \times 10^{-23} \mathrm{~J} / \mathrm{k}\right)$.

$T$ is temperature.

$\Delta \in$ is difference in energy between ground state and excited states.

$P_{1}$ are number of states having equal energy at energy interval $E_{1}$.

$P_{0}$ are number of states having equal energy at energy interval $E_{0}$.

\subsection{Detection Limit}

The detection limit is the lowest concentration of an analyte that can be distinguished with reasonable confidence from a field blank

$$
D=C \times 3 \sigma / A
$$

Block diagram of spectrophotometer is shown in Figure 3.

An optical arrangement is shown in Figure 4.

\section{Materials and Methods}

Blood samples of epileptic patients along with normal healthy control were collected from Department of Neurology, Safdarjang Hospital, New Delhi 110016 after the approval of ethical committee of the hospital. $10 \mathrm{ml}$. freshly drawn blood from each patient was collected in clean and dry test tube without any anti-coagulant. The test tube was kept for 45 minutes at room temperature $\left(22^{\circ} \mathrm{C} \pm 2^{\circ} \mathrm{C}\right)$ for the formation of clot. Sera of different patients were separated by centrifugation at 1500 r.p.m. upto 15 minutes and were collected in screw capped test tubes.

The atomic absorption spectral estimation of the serum samples from normal persons and epileptic patients were carried out on atomic absorption spectrophotometer Model No. AA-6300 of Shimadzu Japan, at Dept. Environmental study University of Delhi 110007.

\section{Results}

We have measured the values of trace elements such as $\mathrm{Cu}, \mathrm{Fe}, \mathrm{Zn}, \mathrm{Na}, \mathrm{K}, \mathrm{Ca}$, and $\mathrm{Mg}$, in epileptic patients and healthy normal control given in Table 2 and Table 3 along with the latest availability of the literate.

We have given the normal limits of radiation and detection in Table 4.

Regression coefficient and multiple correlation coefficients were also given in the Table 5 and Table 6.

Multiple correlation coefficients are given in Table 7.

Student " $\mathrm{t}$ " test was applied to all the trace elements and it was trailed for two tailed t test with unpaired and paired values and given in Table 8 and Table 9.

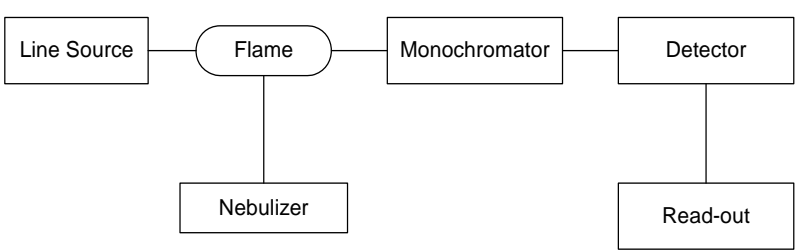

Figure 3. Block diagram of a flame spectrophotometer.

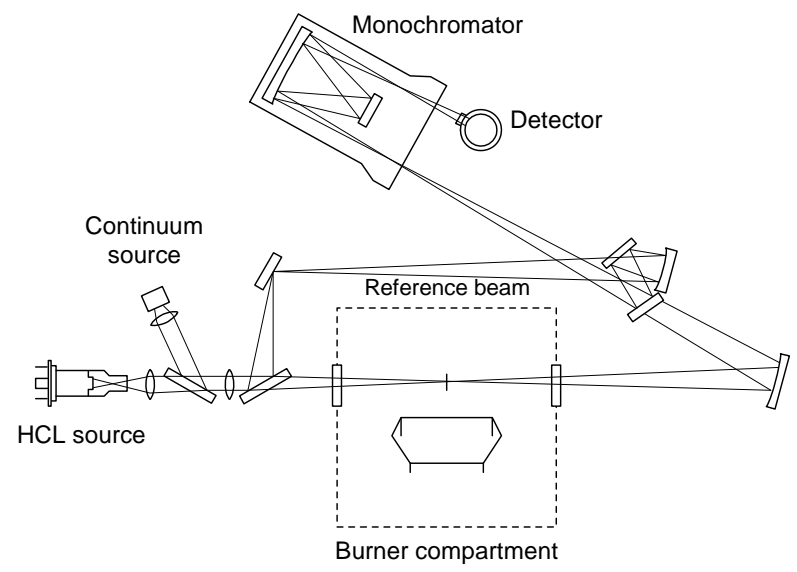

Figure 4. Optical arrangement of atomic absorption spectrophotometer. 
Table 2. Values of trace elements analysis $\mathrm{Cu}, \mathrm{Fe}, \mathrm{Zn}, \mathrm{Na}, \mathrm{K}, \mathrm{Ca}$, and $\mathrm{Mg}$.

\begin{tabular}{|c|c|c|c|c|c|c|c|c|}
\hline S.No. & Type of Samples & a) Сu ppm & Fe ppm & Zn ppm & Na ppm & K ppm & Ca ppm & Mg ppm \\
\hline 1. & $\mathrm{E}$ & 0.5137 & 5.7896 & 5.3516 & 3.220 & 0.1560 & 4.2123 & 4.0989 \\
\hline 2. & $\mathrm{E}$ & 0.1817 & 0.0081 & 5.5081 & 3.2890 & 0.1677 & 3.9312 & 3.8691 \\
\hline 3. & $\mathrm{E}$ & 0.1632 & 0.0998 & 1.4843 & 3.2890 & 0.1482 & 4.5626 & 5.0965 \\
\hline 4. & E & 0.1966 & 0.5854 & 2.1457 & 3.312 & 0.1560 & 2.7946 & 4.1834 \\
\hline 5. & E & 0.2281 & 4.7711 & 4.3873 & 3.266 & 0.1482 & 3.1551 & 5.9011 \\
\hline 6. & E & 0.2058 & 0.5234 & 0.0909 & 3.220 & 0.1443 & 2.6317 & 6.0695 \\
\hline 7. & E & 0.0074 & 3.2280 & 0.3029 & 3.243 & 0.1560 & 4.1817 & 3.9365 \\
\hline 8. & E & 0.1261 & 1.1992 & 0.4089 & 3.266 & 0.1638 & 5.7542 & 3.9365 \\
\hline 9. & E & 0.1372 & 2.3539 & 0.7775 & 3.266 & 0.1521 & 3.5584 & 3.9365 \\
\hline 10. & E & 0.0742 & 3.6488 & 0.4392 & 3.151 & 0.1677 & 5.5037 & 5.9893 \\
\hline 11. & E & 0.1057 & 0.1187 & 0.5251 & 3.243 & 0.1482 & 0.00 & 0.00 \\
\hline 12. & E & 0.1167 & 1.9661 & 2.3099 & 3.151 & 0.1443 & 0.00 & 0.00 \\
\hline 13. & E & 0.2521 & 3.2284 & 0.4178 & 3.289 & 0.1638 & 0.00 & 0.00 \\
\hline 14. & E & 0.1482 & 1.1420 & 1.4504 & 3.312 & 0.1794 & 0.00 & 0.00 \\
\hline 15. & E & 0.2094 & 0.6168 & 0.8526 & 2.921 & 0.1638 & 0.00 & 0.00 \\
\hline 16. & E & 0.1612 & 0.2945 & 0.5487 & 3.197 & 0.1560 & 0.00 & 0.00 \\
\hline 17. & $\mathrm{~N}$ & 0.1242 & 0.7014 & 1.4944 & 3.082 & 0.1404 & 0.0105 & 0.1607 \\
\hline 18. & $\mathrm{~N}$ & 0.0742 & 1.1412 & 0.8027 & 2.990 & 0.1482 & 0.1051 & 0.1117 \\
\hline 19. & $\mathrm{~N}$ & 0.1261 & 1.1439 & 2.1356 & 3.128 & 0.1443 & 0.0394 & 0.1382 \\
\hline 20. & $\mathrm{~N}$ & 0.1113 & 0.4505 & 0.5705 & 3.105 & 0.1404 & 0.0578 & 0.1019 \\
\hline 21. & $\mathrm{~N}$ & 0.1187 & 0.1619 & 0.5856 & 3.220 & 0.1521 & 0.042 & 0.1186 \\
\hline 22. & $\mathrm{~N}$ & 0.1168 & 0.0594 & 0.8482 & 3.220 & 0.1443 & 0.0578 & 0.1137 \\
\hline 23. & $\mathrm{~N}$ & 0.1558 & 0.6111 & 1.2874 & 3.128 & 0.1482 & 0.0499 & 0.0608 \\
\hline 24. & $\mathrm{~N}$ & 0.1598 & 5.7895 & 0.0240 & 3.082 & 0.1404 & 0.0394 & 0.1176 \\
\hline 25. & $\mathrm{~N}$ & 0.2094 & 0.5850 & 1.4921 & 3.128 & 0.1404 & 0.0079 & 0.0588 \\
\hline
\end{tabular}

\section{Discussion}

We have calculated regression coefficiens, regression lines and multiple correlation coefficients between $\mathrm{Na}, \mathrm{K}$, $\mathrm{Ca}, \mathrm{Mg}, \mathrm{Cu}, \mathrm{Zn}$, and $\mathrm{Fe}$. It has been noticed that the value of $\mathrm{R}_{\mathrm{Na} . \mathrm{KCa}}$ and $\mathrm{R}_{\mathrm{Fe} . \mathrm{CuZn}}$ are found to be less correlated and go down upto $49 \%$ and $43 \%$ respectively while other correlations such as $\mathrm{R}_{\mathrm{K} . \mathrm{NaCa}}, \mathrm{R}_{\mathrm{Ca} . \mathrm{K} . \mathrm{Na}}, \mathrm{R}_{\mathrm{Mg} . \mathrm{NaK}}$ $\mathrm{R}_{\mathrm{Na.MgK}}, \mathrm{R}_{\mathrm{K} . \mathrm{MgNa}}, \mathrm{R}_{\mathrm{Cu} . \mathrm{FeZn}}, \mathrm{R}_{\mathrm{Zn.FeCu}}$ are found to be higher than normal values and strongly correlated with each other.

Many of the essential elements are required for human health and occasionally the margin between minimum needs and maximum tolerance of is very feeble. The chemical form of the trace element and the interactions between different trace elements included in the diet are also important in deciding between health and hazard. If we are able to monitor foods and environment for the effects of pollution therefore demands sublety and an awareness of the complexity. It has been apparent that many trace elements play an important role in the maintenance of human health and that an imbalance in trace elements may be a significant factor in a number of physical and neurological conditions. The imbalance may occur as an excess of an element or a deficiency of an element. Most of the elements can become toxic if the level in the body rises above a minimum or standard value.

The importance of nutritional states in maintaining the physical well-being of the human system is very well understandable but the role of diet, including metabolism of dietary constituents is much less well understood.

We have shown the importance and relevance of the results obtained by us in convulsive seizures and the possible mechanisms.

Trace elements act as catalytic agents for enzyme systems of the cells. These elements play a role in enzyme reactions range from weak, ionic strength effects to highly specific associations known as metalloenzymes. Metal is firmly associated with the protein and there is a fixed number of atoms per molecule of protein which can not be removed from this association by dialysis. Removal of the metal by more drastic means leads to loss in the activity of enzyme. This loss can not be restored readily either by re-addition of the metal.

The minimum requirements of living creatures for the essential trace elements are expressed in proportions or concentrations of the total dry food taken daily. The maximum intake of elements within the normal limits of 
Table 3. Results along with work carried out by researchers on different mode of analysis using different types of samples and diseases.

\begin{tabular}{|c|c|c|c|c|c|}
\hline S. No. & Element & Type of sample & Mean + S.D. & Disease & Reference \\
\hline 1. & Calcium & Serum & $(9.0 \pm 0) \mathrm{mg} / 100 \mathrm{ml}$ & Epileptic & John, H. et al. [64] \\
\hline 2. & Calcium & Serum & $(10.47 \pm 1.16) \mu \mathrm{g} / \mathrm{dl}$ & Epileptic & Prasad, R. et al. [72] \\
\hline 3. & Calcium & Serum & $(10.76 \pm 3.29) \mu \mathrm{g} / \mathrm{dl}$ & Controls & Prasad, R. et al. [72] \\
\hline 4. & Calcium & Hair & $(906 \pm 796) \mu \mathrm{g} / \mathrm{g}$ & Controls & Lech, T. et al. [77] \\
\hline 5. & Calcium & Hair & $(520 \pm 436) \mu \mathrm{g} / \mathrm{g}$ & Neurological disorders & Lech, T. et al. [77] \\
\hline 6. & Calcium & Hair & $(960 \pm 419) \mu \mathrm{g} / \mathrm{g}$ & Controls & Avci et al. [78] \\
\hline 7. & Calcium & Hair & $(1162 \pm 533) \mu \mathrm{g} / \mathrm{g}$ & Controls & Avci et al. [78] \\
\hline 8. & Calcium & Hair & $(947 \pm 850) \mu \mathrm{g} / \mathrm{g}$ & Epileptic & Avci et al. [78] \\
\hline 9. & Calcium & Hair & $(1143 \pm 437) \mu \mathrm{g} / \mathrm{g}$ & Epileptic & Avci et al. [78] \\
\hline 10. & Calcium & CSF & $(6.47 \pm 0.87) \mu \mathrm{g} / \mathrm{dl}$ & Controls & Prasad, R. et al. [72] \\
\hline 11. & Calcium & CSF & $(5.85 \pm 2.49) \mu \mathrm{g} / \mathrm{dl}$ & Epilepsy & Prasad, R. et al. [72] \\
\hline 12. & Calcium & Serum & $(2.46 \pm 0.09) \mu \mathrm{g} / \mathrm{dl}$ & Controls & Barlow, P. J. et al. [83] \\
\hline 13. & Calcium & Serum & $(2.41 \pm 0.08) \mu \mathrm{g} / \mathrm{dl}$ & Hyperactive children & Barlow, P. J. et al. [83] \\
\hline 14. & Calcium & Hair & $(430 \pm 200) \mu \mathrm{g} / \mathrm{g}$ & Hyperactive children & Barlow, P. J. et al. [83] \\
\hline 15. & Calcium & Hair & $(694 \pm 349) \mu \mathrm{g} / \mathrm{g}$ & Controls & Barlow, P. J. et al. [83] \\
\hline 16. & Copper & Serum & $(38.119 \pm 2.68) \mu \mathrm{g} / \mathrm{dl}$ & Birth Asphyxia & Khanna R. S. et al. [67] \\
\hline 17. & Copper & Serum & $(29.677 \pm 1.611) \mu \mathrm{g} / \mathrm{dl}$ & Controls & Khanna R. S. et al. [67] \\
\hline 18. & Copper & Serum & $(2.328 \pm 0) \mathrm{mg} / \mathrm{l}$ & Smokers & Adnan, M. et al. [62] \\
\hline 19. & Copper & Serum & $(11.28 \pm 0) \mu \mathrm{mol}$ & Neurotoxic & Guidotti, T. L. et al. [66] \\
\hline 20. & Copper & Serum & $(112.9 \pm 41.88) \mu \mathrm{g} / \mathrm{dl}$ & Epileptic & Prasad, R. et al. [72] \\
\hline 21. & Copper & Serum & $(66.46 \pm 9.76) \mu \mathrm{g} / \mathrm{dl}$ & Controls & Prasad, R. et al. [72] \\
\hline 22. & Copper & Serum & $(111.22 \pm 13.06) \mathrm{mg} / \mathrm{l}$ & Controls & Denitz, T. et al. [75] \\
\hline 23. & Copper & Serum & $(112.65 \pm 9.33) \mathrm{mg} / \mathrm{l}$ & Controls & Denitz, T. et al. [75] \\
\hline 24. & Copper & Serum & $(114.55 \pm 7.38) \mathrm{mg} / \mathrm{l}$ & Epileptic & Denitz, T. et al. [75] \\
\hline 25. & Copper & Serum & $(111.45 \pm 5.97) \mathrm{mg} / \mathrm{l}$ & Epileptic & Denitz, T. et al. [75] \\
\hline 26. & Copper & Serum & $(0.86 \pm 0.24) \mathrm{mg} / \mathrm{l}$ & Controls & Soylak, M. et al. [76] \\
\hline 27. & Copper & Hair & $(19 \pm 7) \mu \mathrm{g} / \mathrm{g}$ & Controls & Avci et al. [78] \\
\hline 28. & Copper & Hair & $(16 \pm 8) \mu \mathrm{g} / \mathrm{g}$ & Controls & Avci et al. [78] \\
\hline 29. & Copper & Hair & $(14 \pm 9) \mu \mathrm{g} / \mathrm{g}$ & Epileptic & Avci et al. [78] \\
\hline 30. & Copper & Hair & $(10 \pm 2) \mu \mathrm{g} / \mathrm{g}$ & Epileptic & Avci et al. [78] \\
\hline 31. & Copper & Serum & $(97.9 \pm 0) \mu \mathrm{g} / 100 \mathrm{ml}$ & Controls & Delvis, H. T. et al. [79] \\
\hline 32. & Copper & Serum & $(102.2 \pm 0) \mu \mathrm{g} / 100 \mathrm{ml}$ & Neurological disorders & Delvis, H. T. et al. [79] \\
\hline 33. & Copper & Serum & $(44 \pm 24) \mathrm{mg} / \mathrm{dl}$ & Controls & Kumar, S. et al. [81] \\
\hline 34. & Copper & Serum & $(30 \pm 17) \mathrm{mg} / \mathrm{dl}$ & GME & Kumar, S. et al. [81] \\
\hline 35. & Copper & Serum & $(18 \pm 3) \mathrm{mg} / \mathrm{dl}$ & Epilepsy & Smith and Bone [80] \\
\hline 36. & Copper & Serum & $(18 \pm 6) \mathrm{mg} / \mathrm{dl}$ & Controls & Smith and Bone [80] \\
\hline 37. & Copper & CSF & $(43.34 \pm 19.32) \mu \mathrm{g} / \mathrm{dl}$ & Controls & Prasad, R. et al. [72] \\
\hline 38. & Copper & CSF & $(36.69 \pm 24.89) \mu \mathrm{g} / \mathrm{dl}$ & Epilepsy & Prasad, R. et al. [72] \\
\hline 39. & Copper & Serum & $(82.2 \pm 16.64) \mu \mathrm{g} / \mathrm{dl}$ & Epilepsy & Kaji, H. et al. [82] \\
\hline 40. & Copper & Serum & $(97.3 \pm 23.0) \mu \mathrm{g} / \mathrm{dl}$ & Controls & Kaji, H. et al. [82] \\
\hline 41. & Copper & Hair & $(38.2 \pm 20.5) \mu \mathrm{g} / \mathrm{g}$ & Hyperactive children & Barlow, P. J. et al. [83] \\
\hline 42. & Copper & Hair & $(47.8 \pm 31.7) \mu \mathrm{g} / \mathrm{g}$ & Controls & Barlow, P. J. et al. [83] \\
\hline 43. & Iron & Serum & $(108.636 \pm 13.03) \mu \mathrm{g} / \mathrm{dl}$ & Birth Asphyxia & Khanna R. S. et al. [67] \\
\hline 44. & Iron & Serum & $(91.469 \pm 2.42) \mu \mathrm{g} / \mathrm{dl}$ & Controls & Khanna R. S. et al. [67] \\
\hline 45. & Iron & Hair & $(9 \pm 2) \mu \mathrm{g} / \mathrm{g}$ & Controls & Avci et al. $[78]$ \\
\hline 46. & Iron & Hair & $(15 \pm 9) \mu \mathrm{g} / \mathrm{g}$ & Controls & Avci et al. [78] \\
\hline 47. & Iron & Hair & $(6 \pm 4) \mu \mathrm{g} / \mathrm{g}$ & Epileptic & Avci et al. [78] \\
\hline 48. & Iron & Hair & $(7 \pm 5) \mu \mathrm{g} / \mathrm{g}$ & Epileptic & Avci et al. [78] \\
\hline
\end{tabular}




\section{Continued}

\begin{tabular}{|c|c|c|c|c|c|}
\hline 49. & Iron & Serum & $(386.0 \pm 0) \mu \mathrm{g} / 100 \mathrm{ml}$ & Controls & Delves, H. T. et al. [79] \\
\hline 50. & Iron & Serum & $(373.4 \pm 0) \mu \mathrm{g} / 100 \mathrm{ml}$ & Neurological disorders & Delves, H. T. et al. [79] \\
\hline 51. & Iron & Serum & $(20 \pm 8) \mathrm{mg} / \mathrm{dl}$ & Controls & Kumar, S. et al.[81] \\
\hline 52. & Iron & Serum & $(29 \pm 15) \mathrm{mg} / \mathrm{dl}$ & GME & Kumar, S. et al.[81] \\
\hline 53. & Iron & Hair & $(8.8 \pm 3.0) \mu \mathrm{g} / \mathrm{g}$ & Hyperactive children & Barlow, P. J. et al. [83] \\
\hline 54. & Iron & Hair & $(15.7 \pm 10.6) \mu \mathrm{g} / \mathrm{g}$ & Controls & Barlow, P. J. et al. [83] \\
\hline 55. & Magnesium & Serum & $(0.87 \pm 0.34) \mu \mathrm{g} / \mathrm{dl}$ & Epileptic & Prasad, R. et al. [72] \\
\hline 56. & Magnesium & Serum & $(0.93 \pm 0.18) \mu \mathrm{g} / \mathrm{dl}$ & Controls & Prasad, R. et al. [72] \\
\hline 57. & Magnesium & Serum & $(24.13 \pm 0.81) \mathrm{mg} / \mathrm{l}$ & Epileptic & Denitz, T. et al. [75] \\
\hline 58. & Magnesium & Serum & $(19.44 \pm 0.53) \mathrm{mg} / \mathrm{l}$ & Epileptic & Denitz, T. et al. [75] \\
\hline 59. & Magnesium & Serum & $(24.33 \pm 2.74) \mathrm{mg} / \mathrm{l}$ & Controls & Denitz, T. et al. [75] \\
\hline 60. & Magnesium & Serum & $(19.50 \pm 0.64) \mathrm{mg} / \mathrm{l}$ & Controls & Denitz, T. et al. [75] \\
\hline 61. & Magnesium & Hair & $(40.5 \pm 32.9) \mu \mathrm{g} / \mathrm{g}$ & Controls & Lech, T. et al. [77] \\
\hline 62. & Magnesium & Hair & $(29.3 \pm 25.3) \mu \mathrm{g} / \mathrm{g}$ & Neurological disorders & Lech, T. et al. [77] \\
\hline 63. & Magnesium & Hair & $(259 \pm 76) \mu \mathrm{g} / \mathrm{g}$ & Controls & Avci et al. [78] \\
\hline 64. & Magnesium & Hair & $(505 \pm 219) \mu \mathrm{g} / \mathrm{g}$ & Controls & Avci et al. [78] \\
\hline 65. & Magnesium & Hair & $(329 \pm 285) \mu \mathrm{g} / \mathrm{g}$ & Epileptic & Avci et al. [78] \\
\hline 66. & Magnesium & Hair & $(444 \pm 203) \mu \mathrm{g} / \mathrm{g}$ & Epileptic & Avci et al. [78] \\
\hline 67. & Magnesium & $\mathrm{CSF}$ & $(1.31 \pm 0.18) \mu \mathrm{g} / \mathrm{dl}$ & Controls & Prasad, R. et al. [72] \\
\hline 68. & Magnesium & CSF & $(1.03 \pm 0.58) \mu \mathrm{g} / \mathrm{dl}$ & Epilepsy & Prasad, R. et al. [72] \\
\hline 69. & Magnesium & Serum & $(0.80 \pm 0.04) \mu \mathrm{mol} / 1$ & Controls & Smith and Bone [80] \\
\hline 70. & Magnesium & Serum & $(0.80 \pm 0.06) \mu \mathrm{mol} / 1$ & Epilepsy & Smith and Bone [80] \\
\hline 71. & Magnesium & Hair & $(53.9 \pm 36.9) \mu \mathrm{g} / \mathrm{g}$ & Hyperactive children & Barlow, P. J. et al. [83] \\
\hline 72. & Magnesium & Hair & $(67.5 \pm 47.4) \mu \mathrm{g} / \mathrm{g}$ & Controls & Barlow, P. J. et al. [83] \\
\hline 73. & Zinc & Serum & $(99.523 \pm 7.44) \mu \mathrm{g} / \mathrm{dl}$ & Birth Asphyxia & Khanna R. S. et al. [67] \\
\hline 74. & Zinc & Serum & $(91.497 \pm 2.44) \mu \mathrm{g} / \mathrm{dl}$ & Controls & Khanna R. S. et al. [67] \\
\hline 75. & Zinc & Serum & $(3.214 \pm 0) \mathrm{mg} / 1$ & Smokers & Adnan, M. et al. [62] \\
\hline 76. & Zinc & Serum & $(8.20 \pm 0) \mu \mathrm{mol}$ & Neurotoxic & Guidotti, T. L. et al. [66] \\
\hline 77. & Zinc & Serum & $(64.82 \pm 18.44) \mu \mathrm{g} / \mathrm{dl}$ & Epileptic & Prasad, R. et al. [72] \\
\hline 78. & Zinc & Serum & $(99.0 \pm 8.0) \mathrm{mg} / \mathrm{l}$ & Controls & Denitz, T. et al. [75] \\
\hline 79. & Zinc & Serum & $(85.90 \pm 2.79) \mathrm{mg} / \mathrm{l}$ & Controls & Denitz, T. et al. [75] \\
\hline 80. & Zinc & Serum & $(56.65 \pm 4.62) \mathrm{mg} / \mathrm{l}$ & Epileptic & Denitz, T. et al. [75] \\
\hline 81. & Zinc & Serum & $(69.75 \pm 3.07) \mathrm{mg} / \mathrm{l}$ & Epileptic & Denitz, T. et al. [75] \\
\hline 82. & Zinc & Hair & $(134.0 \pm 9.41) \mu \mathrm{g} / \mathrm{g}$ & Controls & Denitz, T. et al. [75] \\
\hline 83. & Zinc & Hair & $(136.59 \pm 8.56) \mu \mathrm{g} / \mathrm{g}$ & Controls & Denitz, T. et al. [75] \\
\hline 84. & Zinc & Hair & $(130.5 \pm 7.9) \mu \mathrm{g} / \mathrm{g}$ & Epileptic & Denitz, T. et al. [75] \\
\hline 85. & Zinc & Hair & $(134.0 \pm 7.1) \mu \mathrm{g} / \mathrm{g}$ & Epileptic & Denitz, T. et al. [75] \\
\hline 86. & Zinc & Serum & $(0.54 \pm 0.21) \mathrm{mg} / 1$ & Controls & Soylak, M. et al. [76] \\
\hline 87. & Zinc & Hair & $(200 \pm 61) \mu \mathrm{g} / \mathrm{g}$ & Controls & Avci et al. [78] \\
\hline 88. & Zinc & Hair & $(218 \pm 87) \mu \mathrm{g} / \mathrm{g}$ & Controls & Avci et al. [78] \\
\hline 89. & Zinc & Hair & $(211 \pm 63) \mu \mathrm{g} / \mathrm{g}$ & Epileptic & Avci et al. [78] \\
\hline 90. & Zinc & Hair & $(218 \pm 127 \mu \mathrm{g} / \mathrm{g}$ & Epileptic & Avci et al. [78] \\
\hline 91. & Zinc & Serum & $(510 \pm 0) \mu \mathrm{g} / 100 \mathrm{ml}$ & Controls & Delves, H. T. et al. [79] \\
\hline 92. & Zinc & Serum & $(617.9 \pm 0) \mu \mathrm{g} / 100 \mathrm{ml}$ & Neurological disorders & Delves, H. T. et al. [79] \\
\hline 93. & Zinc & Serum & $(16 \pm 9) \mathrm{mg} / \mathrm{dl}$ & GME & Kumar, S. et al. [81] \\
\hline 94. & Zinc & Serum & $(13 \pm 2) \mathrm{mg} / \mathrm{dl}$ & Epilepsy & Smith and Bone [80] \\
\hline 95. & Zinc & Serum & $(14 \pm 2) \mathrm{mg} / \mathrm{dl}$ & Controls & Smith and Bone [80] \\
\hline 96. & Zinc & CSF & $(5.61 \pm 2.02) \mu \mathrm{g} / \mathrm{dl}$ & Controls & Prasad, R. et al. [72] \\
\hline 97. & Zinc & CSF & $(6.64 \pm 4.40) \mu \mathrm{g} / \mathrm{dl}$ & Epilepsy & Prasad, R. et al. [72] \\
\hline 98. & Zinc & Serum & $(83.2 \pm 11.8) \mu \mathrm{g} / \mathrm{dl}$ & Hyperactive children & Barlow, P. J. et al. [83] \\
\hline
\end{tabular}


Continued

\begin{tabular}{|c|c|c|c|c|c|}
\hline 99. & Zinc & Serum & $(87.6 \pm 12.4) \mu \mathrm{g} / \mathrm{dl}$ & Controls & Barlow, P. J. et al. [83] \\
\hline 100. & Zinc & Hair & $(97.5 \pm 14.7) \mu \mathrm{g} / \mathrm{g}$ & Hyperactive children & Barlow, P. J. et al. [83] \\
\hline 101. & Zinc & Hair & $(123.0 \pm 12.6) \mu \mathrm{g} / \mathrm{g}$ & Controls & Barlow, P. J. et al. [83] \\
\hline 102. & Zinc & Serum & $(1.6875 \pm 1.8156) \mathrm{mg} / \mathrm{l}$ & Epilepsy & Present work \\
\hline 103. & Zinc & Serum & $(1.0267 \pm 0.6347) \mathrm{mg} / \mathrm{l}$ & Control & Present work \\
\hline 104. & Calcium & Serum & $(4.0285 \pm 1.0521) \mathrm{ml} / \mathrm{l}$ & Epilepsy & Present work \\
\hline 105. & Calcium & Serum & $(0.0483 \pm 0.0284) \mathrm{ml} / \mathrm{l}$ & Controls & Present work \\
\hline 106. & Copper & Serum & $(0.1767 \pm 0.1087) \mathrm{mg} / \mathrm{l}$ & Epilepsy & Present work \\
\hline 107. & Copper & Serum & $(0.1329 \pm 0.0380) \mathrm{mg} / \mathrm{l}$ & Control & Present work \\
\hline 108. & Iron & Serum & $(1.8483 \pm 1.8079) \mathrm{mg} / \mathrm{l}$ & Epilepsy & Present work \\
\hline 109. & Iron & Serum & $(1.1826 \pm 1.7671) \mathrm{mg} / \mathrm{l}$ & Control & Present work \\
\hline 110. & Magnesium & Serum & $(4.7017 \pm 0.9548) \mathrm{mg} / \mathrm{l}$ & Epilepsy & Present work \\
\hline 111. & Magnesium & Serum & $(0.1098 \pm 0.0310) \mathrm{mg} / \mathrm{l}$ & Control & Present work \\
\hline 112. & Potassium & Serum & $(0.1572 \pm 0.0098) \mathrm{mg} / \mathrm{l}$ & Epilepsy & Present work \\
\hline 113. & Potassium & Serum & $(0.1443 \pm 0.0043) \mathrm{mg} / \mathrm{l}$ & Control & Present work \\
\hline 114. & Sodium & Serum & (3.2271 \pm 0.0956) mg/l & Epilepsy & Present work \\
\hline 115. & Sodium & Serum & $(3.1203 \pm 0.0708) \mathrm{mg} / \mathrm{l}$ & Control & Present work \\
\hline
\end{tabular}

Table 4. Elements with normal limits of radiation and detection.

\begin{tabular}{cccc}
\hline S. No. & Element & Wavelength & Detection $\mathbf{\mu g} / \mathbf{m l}$ \\
\hline 1. & Calcium & 4227 & 0.08 \\
2. & Copper & 3248 & 0.10 \\
3. & Magnesium & 2852 & 0.01 \\
4. & Potassium & 7665 & 0.03 \\
5. & Sodium & 5890 & 0.03 \\
6. & Iron & 2483 & 0.10 \\
\hline
\end{tabular}

Table 5. Regression and correlation coefficient studies on $\mathrm{Na}, \mathrm{K}, \mathrm{Ca}, \mathrm{Mg}, \mathrm{Zn}, \mathrm{Cu}$ and Fe in epileptic samples.

\begin{tabular}{|c|c|c|c|c|c|}
\hline Diagnosis & $\begin{array}{l}\text { Regression } \\
\text { coefficients }\end{array}$ & $\begin{array}{l}\text { Regression } \\
\text { equations }\end{array}$ & $\begin{array}{c}\text { Coefficient } \\
\text { of correlation }\end{array}$ & $\begin{array}{c}\text { Coefficient of } \\
\text { partial correlation }\end{array}$ & $\begin{array}{l}\text { Multiple correlation } \\
\text { coefficient }\end{array}$ \\
\hline & $b_{\mathrm{Na} . \mathrm{K}}=0.0888$ & $\mathrm{Na}=0.0888 \mathrm{~K}+3.213$ & \multirow{2}{*}{$r_{\mathrm{NaK}}=0.0091$} & $r_{\text {CaNa.K }}=-0.4992$ & $R_{\mathrm{Na} . \mathrm{KCa}}=0.4993$ \\
\hline & $b_{\mathrm{K} . \mathrm{Na}}=0.0009$ & $\mathrm{~K}=0.0009 \mathrm{Na}+0.1541$ & & $r_{\text {CaK.Na }}=-0.7019$ & $R_{\mathrm{K} . \mathrm{NaCa}}=0.7019$ \\
\hline & $b_{\text {Ca.Mg }}=-0.1603$ & $\mathrm{Ca}=-0.1603 \mathrm{Mg}+4.7821$ & \multirow{2}{*}{$r_{\text {CaMg }}=-0.14$} & $r_{\text {NaK.Ca }}=0.3561$ & $R_{\mathrm{K} . \mathrm{NaCa}}=0.7509$ \\
\hline & $b_{\text {Mg.Ca }}=-0.1320$ & $\mathrm{Mg}=-0.1320 \mathrm{Ca}+5.2338$ & & $r_{\mathrm{MgNa}_{\mathrm{K}}}=-0.5366$ & $R_{\mathrm{Mg} \mathrm{NaK}}=0.6206$ \\
\hline & $b_{\text {CuFe }}=0.0254$ & $\mathrm{Cu}=0.0254 \mathrm{Fe}+0.1296$ & \multirow{2}{*}{$r_{\text {CuFe }}=0.42$} & $r_{\mathrm{MgK} . \mathrm{Na}}=-0.4218$ & $R_{\text {Na.MgK }}=0.5367$ \\
\hline & $b_{\mathrm{Fe} \text {. Cu }}=7.0330$ & $\mathrm{Fe}=7.0330 \mathrm{Cu}+0.6055$ & & $r_{\text {NaK.Mg }}=-0.2194$ & $R_{\text {K.MgNa }}=0.4219$ \\
\hline & $b_{\text {Cu.Zn }}=0.0357$ & $\mathrm{Cu}=0.0357 \mathrm{Zn}+0.1163$ & \multirow{2}{*}{$r_{\mathrm{ZnFe}}=0.33$} & $r_{\text {ZnCu.Fe }}=0.5318$ & $R_{\text {Cu.fezn }}=0.6412$ \\
\hline & $b_{\text {zn.Cu }}=9.9642$ & $\mathrm{Zn}=9.9642 \mathrm{Cu}-0.0731$ & & $r_{\text {ZnFe.Cu }}=0.1192$ & $R_{\mathrm{Fe} . \mathrm{CuZn}}=0.4366$ \\
\hline & $b_{\mathrm{Fe}, \mathrm{Zn}}=0.2404$ & $\mathrm{Fe}=0.2404 \mathrm{Zn}+1.4426$ & \multirow{2}{*}{$r_{\mathrm{CuZn}}=0.59$} & \multirow{2}{*}{$r_{\text {Cure.Zn }}=0.2922$} & \multirow{2}{*}{$R_{\text {Zn.Fecu }}=0.6044$} \\
\hline & $b_{\mathrm{Zn.Fe}}=0.4785$ & $\mathrm{Zn}=0.4785 \mathrm{Fe}+0.8030$ & & & \\
\hline
\end{tabular}

the human body is called tolerance. The tolerance may be related as the fertility, growth, health or other relevant criteria of different dietary mineral concentrations.

There are safe dietary levels of potentially toxic trace elements. These depend on the extent to which other elements are present.

Copper and zinc are responsible for the seizures in animals at low dosage administration. It may be probably related to the inhibition of Na-K ATPase activity. We must take care of our body not to take these two elements in sufficient amount. We must take proper intake of the copper and zinc enrich diet of our food.

Magnesium alters calcium metabolism and may stabilize excitable membranes. It has been reported in the literature for the importance of trace metals which may have a role to play in the production of seizures and their 
Table 6. Regression and correlation coefficient studies on $\mathrm{Na}, \mathrm{K}, \mathrm{Ca}, \mathrm{Mg}, \mathrm{Zn}, \mathrm{Cu}$ and Fe. In normal samples.

\begin{tabular}{|c|c|c|c|c|c|c|}
\hline Diagnosis & $\begin{array}{l}\text { Regression } \\
\text { coefficients }\end{array}$ & Regression equations & $\begin{array}{l}\text { Coefficient of } \\
\text { correlation }\end{array}$ & $\begin{array}{c}\text { Coefficient of } \\
\text { partial correlation }\end{array}$ & $\begin{array}{r}\text { Multiple } \\
\text { coef }\end{array}$ & $\begin{array}{l}\text { correlation } \\
\text { fficient }\end{array}$ \\
\hline \multirow{9}{*}{ Normal } & $b_{\mathrm{Na.K}}=4.1282$ & $\mathrm{Na}=4.1282 \mathrm{~K}+2.524$ & \multirow{2}{*}{$r_{\mathrm{NaK}}=0.2539$} & $r_{\text {CaNaK }}=-0.5293$ & $R_{\text {Na.KCa }}$ & $=0.6016$ \\
\hline & $b_{\mathrm{K} . \mathrm{Na}}=0.0156$ & $\mathrm{~K}=0.0156 \mathrm{Na}+0.0955$ & & $r_{\text {CaK.Na }}=0.6316$ & $R_{\mathrm{K} . \mathrm{NaCa}}$ & $=0.6616$ \\
\hline & $b_{\text {Ca.Mg }}=-0.0090$ & $\mathrm{Ca}=-0.0090 \mathrm{Mg}+0.04923$ & \multirow{2}{*}{$r_{\text {CaMg }}=-0.0098$} & $r_{\text {NaK.Ca }}=0.5187$ & $R_{\mathrm{Ca.KNa}}$ & $=0.6894$ \\
\hline & $b_{\mathrm{Mg} . \mathrm{Ca}}=0.0107$ & $\mathrm{Mg}=-0.0107 \mathrm{Ca}+0.1103$ & & $r_{\mathrm{MgNa.K}}=-0.0663$ & $R_{\mathrm{Mg} . \mathrm{NaK}}$ & $=0.1196$ \\
\hline & $b_{\text {Cu.Fe }}=0.0048$ & $\mathrm{Cu}=0.0048 \mathrm{Fe}+0.1272$ & \multirow{2}{*}{$r_{\mathrm{CuFe}}=0.2236$} & $r_{\mathrm{MgK.Na}}=-0.0801$ & $R_{\text {NaMgK }}$ & $=0.2618$ \\
\hline & $b_{\mathrm{FeCu}}=10.3828$ & $\mathrm{Fe}=10.3828 \mathrm{Cu}-0.1974$ & & $r_{\text {NaK.Mg }}=0.2472$ & $R_{\text {K.MgNa }}$ & $=0.2654$ \\
\hline & $b_{\mathrm{Cu} . \mathrm{Zn}}=0.0109$ & $\mathrm{Cu}=0.0109 \mathrm{Zn}+0.1217$ & \multirow{2}{*}{$r_{\text {Cufe }}=-0.4814$} & $r_{\text {ZnCu.fe }}=0.3388$ & $R_{\text {Cu.feZn }}$ & $=0.3988$ \\
\hline & $b_{\mathrm{zn.Cu}}=3.0297$ & $\mathrm{Zn}=3.0297 \mathrm{Cu}+0.6239$ & & $r_{\text {ZnFe.Cu }}=-0.5447$ & $R_{\mathrm{FecCuZn}}$ & $=0.5761$ \\
\hline & $\begin{array}{l}b_{\mathrm{Fe} . \mathrm{Zn}}=-1.3404 \\
b_{\mathrm{Zn} . \mathrm{Fe}}=-0.1729\end{array}$ & $\begin{array}{l}\mathrm{Fe}=-1.3404 \mathrm{Zn}+2.5589 \\
\mathrm{Zn}=-0.1729 \mathrm{Fe}+1.2320\end{array}$ & $r_{\mathrm{Cuzn}}=0.1817$ & $r_{\text {Cufe.Zn }}=0.3610$ & $R_{\text {Zn.Fecu }}$ & $=0.5656$ \\
\hline
\end{tabular}

Table 7. Multiple correlation between trace elements.

\begin{tabular}{|c|c|}
\hline 1. & $\mathrm{R}_{\mathrm{NaKCa}}=0.4993$ (Epilepsy) $=0.6016$ (Normal) \\
\hline 2. & $\mathrm{R}_{\mathrm{K} . \mathrm{NaCa}}=0.7019$ (Epilepsy) $=0.6616$ (Normal) \\
\hline 3. & $\mathrm{R}_{\text {Ca.K. Na }}=0.7509($ Epilepsy $)=0.6894$ (Normal) \\
\hline 4. & $\mathrm{R}_{\mathrm{Mg} \mathrm{NaK}}=0.6206$ (Epilepsy) $=0.1196$ (Normal) \\
\hline 5. & $\mathrm{R}_{\text {Na.MgK }}=0.5367$ (Epilepsy) $=0.2618$ (Normal) \\
\hline 6. & $\mathrm{R}_{\mathrm{K} \text { MgNa }}=0.4219$ (Epilepsy) $=0.2654$ (Normal) \\
\hline 7. & $\mathrm{R}_{\text {Cu.FeZn }}=0.6412$ (Epilepsy) $=0.3988$ (Normal) \\
\hline 8. & $\mathrm{R}_{\mathrm{FeCCuzn}}=0.4366$ (Epilepsy) $=0.5761$ (Normal) \\
\hline 9. & $\mathrm{R}_{\mathrm{Zn.FCCu}}=0.6044$ (Epilepsy) $=0.5656($ Normal $)$ \\
\hline
\end{tabular}

Table 8. Student “ $t$ " test applied on the trace elements two tailed unpaired t test. Two tailed unpaired t-test.

\begin{tabular}{ccccccccc}
\hline S.N & Element & $\mathrm{t}(\exp )$ & $\mathrm{t}($ theo $)$ & $\mathrm{p}$ & $\mathrm{df}$ & Result & Null hypothesis & Conclusion \\
\hline 1 & $\mathrm{Na}$ & 2.9197 & 2.82 & 0.0077 & 23 & $\mathrm{t}($ theo $)<\mathrm{t}(\exp )$ & Accepted & $\begin{array}{c}\text { Not significant } \\
2\end{array}$ \\
$\mathrm{k}$ & 3.7131 & 3.79 & 0.0011 & 23 & $\mathrm{t}($ theo $)>\mathrm{t}(\exp )$ & Rejected & $\begin{array}{c}\text { Differences between the mean K levels of epilepsy } \\
\text { and that of normals is strongly significant }\end{array}$ \\
& & & & & & & Not significant \\
3 & $\mathrm{Ca}$ & 11.319 & 3.97 & 0.0001 & 17 & $\mathrm{t}($ theo $)<\mathrm{t}(\exp )$ & Accepted & Not significant \\
4 & $\mathrm{Mg}$ & 14.380 & 3.97 & 0.0001 & 17 & $\mathrm{t}($ theo $)<\mathrm{t}(\exp )$ & Accepted & Not significant \\
& $\mathrm{Cu}$ & 1.1592 & 0.69 & 0.2583 & 23 & $\mathrm{t}($ theo $)<\mathrm{t}(\exp )$ & Accepted & Not significant \\
$\mathbf{6}$ & $\mathrm{Fe}$ & 0.8906 & 0.69 & 0.3823 & 23 & $\mathrm{t}($ the $)<\mathrm{t}(\exp )$ & Accepted & Not significant \\
7 & $\mathrm{Zn}$ & 1.048 & 0.69 & 0.3055 & 23 & $\mathrm{t}($ theo $)<\mathrm{t}(\exp )$ & Accepted & \\
\hline
\end{tabular}

Table 9. Student “t” test applied on the trace elements two tailed paired t test. $t$ test (two tailed ) paired.

\begin{tabular}{|c|c|c|c|c|c|c|c|c|}
\hline S.N & Element & $\mathrm{t}(\exp )$ & $\mathrm{t}$ (theo) & $\mathbf{p}$ & df & result & Null hypothesis & Conclusion \\
\hline 1 & $\mathrm{Na}$ & 4.9115 & 5.04 & & & $\mathrm{t}($ the $)>\mathrm{t}(\exp )$ & Rejected & $\begin{array}{c}\text { Differences between the mean Na levels of epilepsy } \\
\text { and that of normals is strongly significant }\end{array}$ \\
\hline 2 & $\mathrm{~K}$ & 3.4112 & 3.36 & 0.01 & 8 & $\mathrm{t}($ the $)<\mathrm{t}(\exp )$ & Accepted & Not significant \\
\hline 3 & $\mathrm{Ca}$ & 11.7348 & 5.04 & 0.001 & 8 & $\mathrm{t}($ theo $)<\mathrm{t}(\exp )$ & Accepted & Not significant \\
\hline 4 & $\mathrm{Mg}$ & 15.1212 & 5.04 & 0.001 & 8 & $\mathrm{t}($ the $)<\mathrm{t}(\exp )$ & Accepted & Not significant \\
\hline 5 & $\mathrm{Cu}$ & 1.2355 & 1.8 & 0.2517 & 8 & $t($ the $)>t(\exp )$ & Rejeted & $\begin{array}{l}\text { Differences between the mean } \mathrm{Cu} \text { levels of epilepsy } \\
\text { and that of normals is strongly significant }\end{array}$ \\
\hline 6 & $\mathrm{Fe}$ & 0.8684 & 0.71 & 0.4105 & 8 & $\mathrm{t}($ the $)<\mathrm{t}(\exp )$ & Accepted & Not significant \\
\hline 7 & $\mathrm{Zn}$ & 1.6203 & 1.8 & 0.1483 & 8 & $\mathrm{t}(\mathrm{the})>\mathrm{t}(\exp )$ & Rejected & $\begin{array}{c}\text { Differences between the mean } \mathrm{Zn} \text { levels of epilepsy } \\
\text { and that of normals is strongly significant }\end{array}$ \\
\hline
\end{tabular}


control in human beings.

Zinc, magnesium and copper also play an important biochemical role in the human metabolism. Electro physiological research indicates that some divalent cations, e.g. $\mathrm{Mg}^{++}, \mathrm{Zn}^{++}$, etc. reduce the excitability of control neurons, probably replacing a calcium ion from places of binding.

Epilepsy is a challenging disorder because its mechanisms are not well established. There are so many experimental and human studies demonstrated that the abnormal metabolism of trace elements might be involved in the pathophysiology of this brain disorder related to paroxysmal disturbances.

On the other hand, the number of studies focusing on the trace element levels of epileptic patients prior to and during the treatment is rather limited [86-89].

It has been reviewed and reported in the literature that the living things need 72 biological elements for normal metabolic function, reproduction, and maintenance of the immune system. Calcium is an element which is generally deficient. It is required in every cell in our body and vitally important. If the food is grown on soils which contain all the 72 elements, we may say it is healthy food. Insects and diseases do not attack plants grown in healthy soil. Insects are nature's garbage disposal agents. We choose to kill insects and allow ourselves to eat garbage. Disease is also nature's way of eliminating those things that are not healthy. They maybe plants, animals and humans.

Food we eat is deficient in over sixty vital important elements. The food which is deficient to all such types of elements is the basic cause of large numbers of physiological and mental diseases such as auto immune disease, late onset diabetes, degenerative and chronic diseases, allergies and birth defects and neurological disorders.

It has been established in the literature that the routine cocktail of medications with their complicated interactions and side effects should be rejected. We must provide a chance for minerals, vitamins and essential fatty acids and trace elements for healthy body.

Trace elements are essential in the assimilation and utilization of vitamins. Elements help in the digestion. The elements work as a catalyst for hormones and enzymes. They may work as an aid in replacing electrolytes lost through perspiration. Elements protect against toxic reactions.

Reinstatement of trace elements in our soils eliminates all plant diseases, pests and insect attacks. This eliminates the need for use of toxic agricultural chemicals. We may have a healthy food rather than a food which is deficient to all the trace elements.

We know that living organisms, including humans, are part of environment they reflect what is present in their surroundings. Traces of a large variety of both natural and man-made compounds can be found in the tissues and fluids of humans as a result of exposure to these compounds in air, soil, water, food and consumer products.

Evidences from analysis of foods and water, as well as from direct measurements of fluids and tissues, reveals that the levels of some harmful elements have decreased now a days.

We are able to detect a number of compounds in the human body that results from the use of consumer products, such as pharmaceuticals and dietary supplements, and from lifestyle choices, such as smoking and alcoholism.

The continuous detection of trace elements in human tissues and fluids has led to legitmate concern about the possible health effects of the presence of elements in human body. To evaluate this fact, it is important to understand how these elements are detected, what trends are in the levels, and what is known about the health impacts of the levels that have been detected.

\section{Conclusions}

It has been noticed that the value of potassium in epilepsy in unpaired $t$ test is found strongly significant with normal. For paired group of $t$ test sodium, copper and zinc in epileptic cases were also strongly significant with normal.

It has also been calculated the multiple correlation coefficient and regression correlation coefficients between $\mathrm{Na}, \mathrm{K}, \mathrm{Ca}, \mathrm{Mg}, \mathrm{Cu}, \mathrm{Fe}$, and $\mathrm{Zn}$ and found that the value of $\mathrm{R}_{\mathrm{Na} . \mathrm{KCa}}$ and $\mathrm{R}_{\mathrm{Fe} . \mathrm{CuZn}}$ is less than normal control, while other correlation such as $\mathrm{R}_{\mathrm{K} . \mathrm{NaCa}}, \mathrm{R}_{\mathrm{Ca} . \mathrm{KNa}}, \mathrm{R}_{\mathrm{Mg} . \mathrm{NaK}}, \mathrm{R}_{\mathrm{Na} . \mathrm{MgK}}$, $\mathrm{R}_{\mathrm{K} . \mathrm{MgNa}}, \mathrm{R}_{\mathrm{Cu} . \mathrm{FeZn}}$ and $\mathrm{R}_{\mathrm{Zn.FeCu}}$ are found to be higher than normal values and strongly correlated with each other.

The levels of trace elements of $\mathrm{Na}, \mathrm{K}, \mathrm{Ca}, \mathrm{Mg}, \mathrm{Cu}, \mathrm{Fe}$, and $\mathrm{Zn}$ are found to be higher in all epileptic cases, in comparison to normal healthy control. A major factor in epilepsy has been found to be essential mineral deficiencies and imbalances such as magnesium, zinc, calcium, sodium, potassium etc. Some of the main mechanisms of toxic effects of metal include cytotoxicity, change in cellular membrance, permeability, inhibition of enzymes, coenzymes, and hormones, generation of free radicals, which result in neurotoxicity, immuno-toxicity, impaired cellular respiration, metabolic effects hormonal effects.

In present findings the essential mineral imbalance have been found to be a major factor in epilepsy and correct mineral balance has been found to cause significant improvement in epilepsy.

Supplementation alternations are often beneficial in treatment of seizures and epilepsy. B vitamins, essential minerals, some herbs products, some amino acids, and essentials fatty acids alternation are beneficial to reduce seizures.

From obtained result the levels of trace element are 
increased so that both proper medication and supplement alteration will be effective in the treatment of the epilepsy.

\section{Acknowledgements}

Authors are thankful to Dr. P. K. Saxena Principal, D.A.V. College, Muzaffarnagar, U.P. for providing necessary conditions to carry research.

\section{REFERENCES}

[1] Personalhealthfacts.com, "The Importance of Trace Minerals," NFM's Nutrition Science News, 1985, pp. 1-4.

[2] M. Romeyn, "Vitamins, Minerals and Trace Elements," Nutrition and HIV, Jossey-Bass Inc., San Francisco, 1998.

[3] W. B. Herring, B. S. Leavell, L. M. Paixao and J. H. Yoe, "Trace Metals in Human Plasma and Red Blood Cells," American Journal of Clinical nutrition, Vol. 8, No. 6, 1960, pp. 846-854.

[4] S. J. Khurshid and I. H. Qureshi, "The Role of Inorganic Elements in Human Body," The Nucleus, Vol. 21, No. 4, 1984, pp. 3-23.

[5] R. Suhaila, K. Nasir, A. Shujaat, U. Nasim and Z. I. Mohammad, "Essential Trace Metals in Human Whole Blood in Relation to Environment," Pakistan Journal of Medical Research, Vol. 43, No. 2, 2004, pp. 1-5.

[6] S. Kumar, "Medico-Physical Studies on Epilepsy and Other Neurological Disorders," Ph.D. Thesis, University of Delhi, India, 1989.

[7] R. L. A. Mary, A. C. Kelvin, D. Sheila and H. R. William, "Nutrient Risk Assessment Implication for Food Fortification Policy," In: A. M. Rousel, R. A. Anderson and A. Favrier, Eds., Trace Elements in Man and Animals-10, Kluwer Academic Publications, New York, Dodrecht, 2000, pp. 215-220.

[8] G. S. Alexander, "Minerals and Human Health: The Rationale for Optimal and Balanced Trace Element Levels," Life Sciences Press, Tacoma, 1995, pp. 1-5.

[9] R. L. Pike and M. L. Brown, "An Integrated Approach," Nutrition, John Wiley \& Sons, 1984, p. 197.

[10] H. Zumkley, "Trace Elements in Medicine," Fresenius' Zeitschrift Für Analytische Chemie, Vol. 327, No. 1, 1987, p. 6. http://dx.doi.org/10.1007/BF00474512

[11] I. J. J. Davies, "Clinical Significance of the Essential Biological Metals," In: Animal Health and Hygiene (General), William Heineman, London, 1972, pp. 48-126.

[12] R. R. Burns and G. S. Fell, "Estimation and Interpretation of Plasma Zinc Fractions," Scottish Medical Journal, Vol. 21, No. 3, 1976, pp. 153-154.

[13] A. S. Prasad and D. Oberleas, "Binding of Zinc to Amino Acids and Serum Proteins in Vitro," Journal of Laboratory and Clinical Medicine, Vol. 76, No. 3, 1970, pp. 416-425.

[14] D. Kelin and J. Mann, "Carbonic Anhydrase: Purification and Nature of the Enzyme," Biochemical Journal, Vol. 34,
No. 8-9, 1940, pp. 1163-1176.

[15] J. F. Riordan and B. L. Vallee, "Structure and Function of Zinc Metalloenzymes," In: A. S. Prasad, Ed., Trace Elements in Human Health and Disease, Vol. 1, Academic Press, New York, 1976, pp. 227-251.

[16] M. Chavapil, C. F. Zukowski, B. G. Hattler, L. Stankova, D. Montgomery, E. C. Carlson and J. C. Ludwig, "Zinc and Activity of Cell Membrane," In: A. S. Prasad, Ed., Trace-Elements in Human Health and Disease, Vol. 1, Academic Press, New York, 1976, pp. 269-281.

[17] A. S. Prasad, A. R. Schulert, H. H. Sandstead, A. Miale Jr. and Z. Farid, "Zinc, Iron and Nitrogen Content of Sweat in Normal and Deficient Subjects," Journal of Laboratory and Clinical Medicine, Vol. 62, 1963, pp. 84-89.

[18] P. A. Walravens, W. J. V. Doornick and K. M. Hambidge, "Metals and Mental Function," Journal of Pediatrics, Vol. 93, No. 3, 1978, p. 535. http://dx.doi.org/10.1016/S0022-3476(78)81194-9

[19] R. I. Henkin, B. M. Patten, P. K. Re and D. A. Bronzett, "A Syndrome of Acute Zinc Loss," JAMA, Vol. 32, No. 11, 1975, pp. 745-751. http://dx.doi.org/10.1001/archneur.1975.00490530067006

[20] I. E. Dresti, "Zinc in the Central Nervous System: The Emerging Interactions," In: C. J. Frederickson, G. A. Howell and E. J. Kasarskis, Eds., The Neurobiology of Zinc Part A, R. L. Alan, New York, 1984, pp. 1-26.

[21] V. F. Fairbanks, J. L. Fahey and E. Beutler, "Clinical Disorders of Iron Metabolism," 2nd Edition, Grune and Stratton, New York, 1971, pp. 1-486.

[22] Mc Cance and E. M. Widdowson, "Absorption and Excretion of Iron," Lancet, Vol. 2, 1973, pp. 680-684.

[23] S. Gramick, "Ferritin IX. Increase of the Protein Apoferritin in the Gastrointestinal Mucosa as a Direct Response to Iron Feeding. The Function of Ferritin in the Regulation of Iron Absorption," Journal of Biological Chemistry, Vol. 164, 1946, pp. 737-746.

[24] C. V. Moore, C. A. Doan and W. R. Arrowsmith, "Studies in Iron Transportation and Metabolism, Mechanism of Iron Transportations: Its Significance in Iron Utilization in Anemic States of Varied Etiology," Journal of Clinical Investigation, Vol. 16, No. 4, 1973, pp. 627-648. http://dx.doi.org/10.1172/JCI100889

[25] H. R. Mahler and D. G. Elowe, "DPNH Cytochrome Reductase, a Ferroflavo Protein," Journal of the American Chemical Society, Vol. 75, No. 22, 1953, pp. 5769-5770. http://dx.doi.org/10.1021/ja01118a536

[26] D. A. Richert and W. W. Westerfeld, "The Relationship of Iron to Xanthime Oxidase," Journal of Biological Chemistry, Vol. 209, 1954, pp. 179-189.

[27] H. Fisher and K. Zeile, "Synthesis of Hematoprophyrin, Protoporphyrin and Hemin," European Journal of Organic Chemistry, Vol. 468, No. 1, 1929, pp. 98-116.

[28] D. J. E. Ingram, J. W. Fibson and M. F. Perutz, "Orientation of the Four Heme Groups in Hemoglobin," Nature, Vol. 178, 1956, pp. 906-908. http://dx.doi.org/10.1038/178906a0

[29] G. C. Holmberg and C. B. Laurell, "Investigations in Serum Copper I. Nature of Serum Copper and Its Relation 
to the Iron-Binding Protein in Human Serum," Acta Chemica Scandinavica, Vol. 1, No. 10, 1974, pp. 944950.

[30] A. L. Schade, R. W. Reinhart and H. Levy, "Carbon Dioxide and Oxygen in Complex Formation with Iron and Siderophilin, the Iron-Binding Compound of Human Plasma," Archives of Biochemistry and Biophysics, Vol. 20, No. 1, 1949, pp. 170-172.

[31] D. A. Lipschitz, J. D. Cook and C. A. Finch, "A Clinical Evaluation of Serum Ferritin as an Index of Iron Stores," New England Journal of Medicine, Vol. 290, No. 22, 1974, pp. 1213-1216. http://dx.doi.org/10.1056/NEJM197405302902201

[32] M. A. Simes, J. E. Addiego Jr. and P. R. Dallman, "Ferritin in Serum: Diagnosis of Iron Deficiendcy and Iron Overload in Infants and Children," Blood, Vol. 43, No. 4, 1974, pp. 581-590.

[33] J. K. Aikawa, "The Relationship of Magnesium to Diseases in Domestic Animals and in Human," C. Charles, Thomas, Springfield, Illinois, 1971, pp. 1-145.

[34] J. K. Aikawa, "Biochemistry and Physiology of Magnesium," In: A. S. Prasad, Ed., Trace Elements in Humans: Health and Diseases, Vol. II, Academic Press, New York, 1976, pp. 47-78.

[35] E. M. Widdowson, R. A. McCance and C. N. Spray, "The Clinical Composition of the Human Body," Clinical Science, Vol. 10, 1951, pp. 113-125.

[36] J. C. Waterlow, "Endocrine Changes in Severe PEM," In: J. C. Waterlow, Ed., Protein-Energy Malnutrition, Edward Arnold, London, 1992, pp. 112-125.

[37] H. G. Classen, "Magnesium and Potassium Deprivation and Supplementation in Animals and Man: Aspects in View of Intestinal Absorption," Magnesium, Vol. 3, No. 4-6, 1984, pp. 257-264.

[38] S. M. Al-Ghamdi, E. C. Cameron and R. A. Sutten, "Magnesium deficiency: Pathophysiologic and Clinical Overview," American Journal of Kidney Disease, Vol. 24, No. 5, 1994, pp. 737-752.

[39] P. Wester, "Magnesium," The American Journal of Clinical Nutrition, Vol. 45, 1987, pp. 1305-1312.

[40] B. Krasner, "Cardiac Effects of Magnesium with Special Reference to Anaesthesia: A Review," Canadian Anaesthetists' Society Journal, Vol. 26, No. 3, 1979, pp. 181185. http://dx.doi.org/10.1007/BF03006978

[41] Y. Furukawa and S. Chiba, "Effects of Magnesium on the Isolated, Blood-Perfused Atrial and Ventricular Preparations of the Dog Heart," Japanese Heart Journal, Vol. 22, No. 2, 1981, pp. 239-246. http://dx.doi.org/10.1536/ihj.22.239

[42] G. Stark, U. Stark, E. Pilger, K. Honigl, H. Bertuch and H. A. Tritthart, "The Influence of Elevated $\mathrm{Mg}^{2+}$ Concentrations on Cardiac Electrophysiological Parameters," Cardiovascular Drugs and Therapy, Vol. 3 No. 2, 1989, pp. 183-189. http://dx.doi.org/10.1007/BF01883863

[43] M. C. PHaigney, R. Berger, S. Schulman, G. Gerstenblith, C. Tunin. B. Silver, H. S. Silverman, G. Tomaselli and H. Calkins, "Tissue Magnesium Levels and the Arrhythmic Substrate in Humans," Journal of Cardiovascular Elec- trophysiology, Vol. 8, No. 9, 1997, pp. 980-986. http://dx.doi.org/10.1111/j.1540-8167.1997.tb00620.x

[44] P. Ireland and J. S. Fordtran, "Effect of Dietary Calcium and Age on Jejunal Calcium Absorption in Humans Studied by Intestinal Perfusion," Journal of Clinical Investigation, Vol. 52, No. 11, 1973, pp. 2672-2681. http://dx.doi.org/10.1172/JCI107461

[45] R. P. Heaney, P. D. Saville and R. R. Recker, "Calcium Absorption as a Function of Calcium Intake," Journal of Laboratory and Clinical Medicine, Vol. 85, No. 6, 1975, pp. 881-890.

[46] R. Wilkinson, "Absorption of Calcium, Phosphorus and Magnesium Calcium Phosphate and Magnesium Metabolism," In: B. E. C. Nordin, Ed., Churchill Livingstone, Edinberg, 1976, pp. 36-112.

[47] D. H. Marshall, "Calcium and Phosphate Kinetics Calcium, Phosphate and Magnesium Metabolism," In: B. E. C. Nordin, Ed., Churchill Livingstone, Edinberg, 1976, pp. 257-297.

[48] H. A. Morris, A. G. Need, M. Horowitz, P. D. O'Loughlin and B. E. Nordin, "Calcium Absorption in Normal and Osteoporotic Postmenopausal Women," Calcified Tissue International, Vol. 49, No. 4, 1991, pp. 240-243. http://dx.doi.org/10.1007/BF02556211

[49] P. R. Ebeling, A. L. Yergey and N. E. Vleira, "Influence of Age on Effects of Endogeneous 1, 25-Dihydroxyvitamin D on Calcium Absorption in Normal Women," Calcified Tissue International, Vol. 55, No. 5, 1994, pp. 330334. http://dx.doi.org/10.1007/BF00299309

[50] A. G. Need, H. A. Morris, M. Horowitz, E. Scopacasa and B. E. Nordin, "Intestinal Calcium Absorption in Men with Spinal Osteoporosis," Clinical Endocrinology, Vol. 48, No. 2, 1998, pp. 163-168. http://dx.doi.org/10.1046/j.1365-2265.1998.3681181.x

[51] B. E. C. Nordin, "Nutritional Considerations," In: B. E. C. Nordin, Ed., Calcium, Phosphate and Magnesium Metabolism, Churchill Livingstone, Edinberg, 1976, pp. 135 .

[52] G. N. Kent, R. I. Price and D. H. Gutteridge, J. R. Allen, M. P. Barnes, G. J. Hickling, R. W. Retallack, S. G. Wilson, R. D. Delvin, R. I. Price, M. Simith, C. I. Bhagat, C. Davies and A. St. Johns, "Human Lactation: Forearm Trabecular Bone Loss, Increased Bone Turnover, and Renal Conservation of Calcium and Inorganic Phosphate with Recovery of Bone Mass Following Weaning," Journal of Bone and Mineral Research, Vol. 5, No. 4, 1990, pp. 361-369. http://dx.doi.org/10.1002/jbmr.5650050409

[53] J. M. Lopez, G. Gonzalez, V. Reyes, C. Campino and S. Diaz, "Bone Turnover and Density in Healthy Women during Breastfeeding and after Weaning," Osteoporosis International, Vol. 6, No. 2, 1996, pp. 153-159. http://dx.doi.org/10.1007/BF01623940

[54] G. M. Chan, M. McMurray, K. Westover, K. EngelbertFenton and M. R. Thomas, "Effects of Increased Dietary Calcium Intake upon the Calcium and Bone Mineral Status of Lacting Adolescent and Adult Women," American Journal of Clinical Nutrition, Vol. 46, No. 2, 1987, pp. 319-323.

[55] M. Katz and E. R. Steihm, "Host Defense in Malnutri- 
tion," Pediatrics, Vol. 59, No. 4, 1977, pp. 490-495.

[56] R. M. Suskind, "Malnutritian and the Immune Response," Kroc Foundation Series (USA), Vol. 7, Raven Press, New York, 1977, p. 468.

[57] I. B. Bongiorni-Malave and M. Pocino, "Abnormal Regulatory Control of the Antibody Response to Hetrologous Erythrocytes in Protein-Calorie-Malnourished Mice," Clinical Immunology and Immunopathology, Vol. 16 No. 1, 1980, pp. 19-29. http://dx.doi.org/10.1016/0090-1229(80)90162-2

[58] I. Malave, A. Nemeth and M. Pocino, "Changes in Lymphocyte Populations in Proteins - Calorie-Deficient Mice," Cellular Immunology, Vol. 49, No. 2, 1980, pp. 235-249.

[59] M. E. Gershwin, C. L. Keen, M. P. Fletcher and L. S. Hurley, "Trace Element Deficiencies and Immune Responsiveness,” In: L. S. Hurley, C. L. Keen, Bo. Lonnerdal and R. B. Rucker, Eds., Trace Elements in Man and Animals, Plenuum Press, New York and London, 1988, pp. 85-89.

[60] D. A. Rigas, E. C. Rigas and C. Head, "Biophasic Toxicity of Diethyldithiocarbamate, a Metal Chelator, to $\mathrm{T}$ Leymphocytes and Polymorphonucuclear Granulocytes: Reversal by Zinc and Copper," Biochemical and Biophysical Research Communications, Vol. 88, No. 2, 1979, pp. 373-379. http://dx.doi.org/10.1016/0006-291X(79)92058-8

[61] P. Bratter, A. Raab and A. N. Richarz, "Trace Elements Speciation in Human Body Fluids," In: A. E. Favier, A. N. Roussel and R. A. Anderson, Eds., Trace Elements in Man and Animals, International Symposium 10th, Trace Elements in Man and Animals, Kluwer Academic/Plenum Publishers, New York, 2000, pp. 145-152.

[62] M. Adnan, G. Ahmed, O. Khaled, A. M. Indress, A. Ahmed, T. Hiatham and H. Wall, "Simultaneous Determination of $\mathrm{Cd}, \mathrm{Pb}, \mathrm{Cu}, \mathrm{Zn}$ and $\mathrm{Se}$ in Human Blood of Jordanian Smokers, by ICP-OES," Biological Trace Element Research, Vol. 133, No. 1, 2010, pp. 1-11. http://dx.doi.org/10.1007/s12011-009-8405-y

[63] E. Keck, B. Gollnick, D. Reinhardt, D. Karch, H. Peerenboom and H. L. Kruskemper, "Calcium Metabolism and Vitamin D Metabolite Levels in Children Receiving AntiConvulsant Drugs," European Journal of Pediatrics, Vol. 139, No. 1, 1982, pp. 52-55. http://dx.doi.org/10.1007/BF00442080

[64] H. John, J. D. Maxwell, D. A. Stewart, V. Parsons and R. Williams, "Altered Calcium Metabolism in Epileptic Children on Anti-Convulsants," British Medical Journal, Vol. 4, No. 5781, 1971, pp. 202-204.

[65] B. H. William, B. S. Leavell, L. M. Paixao and H. Y. John, "A Study of Magnesium, Chromium, Nickel, Copper and Zinc I. Observation of Normal Subjects," American Journal of Clinical Nutrition, Vol. 8, 1960, pp. 846854.

[66] T. L. Guidotti, J. McNamara and M. S. Moses, "The Interpretation of Trace Element Analysis in Body Fluids," The Indian Journal of Medical Research, Vol. 128, No. 4, 2008, pp. 524-532.

[67] R. S. Khanna, R. Kumar, R. A. Asthana, R. Negi, D. Pande, A. Kumar and H. D. Khanna, "Role of Trace Ele- ment and Antioxidants in Free Radical Mediated Injury in Neonates," MASAUM Journal of Basic and Applied Sciences, Vol. 3, No. 1, 2009, pp. 543-547.

[68] W. J. Walsh, H. R. Isaacson, F. Rehman and A. Hall, "Elevated Blood Copper/Zinc Ratio in Assaultive Young Males," Physiology \& Behavior, Vol. 62, No. 2, 1997, pp. 327-329. http://dx.doi.org/10.1016/S0031-9384(97)88988-3

[69] J. F. Pamela, J. Paula and C. John, "Zinc Deficiency and Immune Function," JAMA, Vol. 123, No. 12, 1987, pp. 1699-1701.

http://dx.doi.org/10.1001/archderm.1987.01660360152028

[70] I. I. Atilla, O. Elit, G. Mukaddes, I. I. K. Bunyamin, I. I. Nevin, Y. I. Neciip and A. Omer, "The Comparison of Nail and Serum Trace Elements in Patients with Epilepsy and Healthy Subjects," Progress in Neuro-Psychopharmacology \& Biological Psychiatry, Vol. 28, No. 1, 2004, pp. 99-104.

[71] J. C. Smith Jr., G. P. Butrimovitz, W. C. Purdy, R. L. Boeckx, R. Chu, M. E. McIntosh, K. D. Lee, J. K. Kynn, E. C. Dinovo, A. S. Prasad and H. Spencer, "Direct Measurement of Zinc in Plasma by Atomic Absorption Spectroscopy," Journal of Clinical Chemistry, Vol. 25, No. 8, 1979, pp. 1487-1491.

[72] R. Prasad, A. Singh, B. K. Das, R. S. Upadhyay, T. B. Singh and O. P. Mishra, "Cerebrospinal Fluid and Serum Zinc Copper, Magnesium and Calcium Levels in Children with Idiopathic Seizure," Journal of Clinical and Diagnostic Research, Vol. 3, No. 6, 2009, pp. 1841-1846.

[73] U. Tinggi and W. Maher, "Determination of Trace Element in Biological Tissues by Aluminium Block Digestion and Spike Height Flame Atomic Absorption Spectrometry," Microchemical Journal, Vol. 33, No. 3, 1986, pp. 304-308. http://dx.doi.org/10.1016/0026-265X(86)90003-2

[74] J. B. Willis, "Determination of Magnesium in Blood Serum by Atomic Absorption Spectroscopy," Nature, Vol. 184, 1959, pp. 186-187. http://dx.doi.org/10.1038/184186a0

[75] T. Deniz, H. T. Ali and R. Saraymen, "The Effects of Antiepileptic Drugs on Serum and Hair Trace Element Levels," Ankara Universitesi Tip Fakultesi Mecmuasi, Vol. 61, No. 2, 2008, pp. 73-76.

[76] M. Soylak, S. Saracoglu, U. Divrikli and L. Elci, "Copper and Zinc Concentrations of Serum Samples of Healthy People Living in Tokat, Turkey," Trace Elements and Electrolytes, Vol. 18, No. 1, 2001, pp. 47-50.

[77] T. Lech, "Calcium and Magnesium Content in Hair as a Predictor of Disease in Children," Trace Elements and Electrolytes, Vol. 18, No. 3, 2001, pp. 112-121.

[78] H. Avci, N. Kizilkan and M. Yaman, "Comparison of Trace Elements Concentrations in Scalp Hair of Epileptic and Normal Subjects," Trace Elements and Electrolytes, Vol. 25, No. 3, 2008, pp. 147-155. http://dx.doi.org/10.5414/TEP25147

[79] H. T. Delves, B. E. Clayton and J. Bicknel, "Concentration of Trace Metals in the Blood of Children," British Journal of Preventive \& Social Medicine, Vol. 27, No. 2, 1973, pp. 100-107. 
[80] W. G. Smith and I. Bone, "Copper, Zinc and Magnesium Plasma Levels in Epilepsy," Journal of Neurology, Neurosurg \& Psychiatry, Vol. 45, No. 11, 1982, p. 1072. http://dx.doi.org/10.1136/jnnp.45.11.1072

[81] S. Kumar, M. Bajaj, D. C. Jain and H. S. Yadav, "A Search for the Trace Elemental Deficiencies in Grand Mal Epilepsy Using Atomic Absorption Spectrophotometric Technique and Catalytic Agent in the Cellular Enzyme Reaction," Proceedings of the World Congress on Clinical Nutrition, Vol. 1, 1988, pp. 115A-121A.

[82] M. Kaji, N. Ito, T. Okuno, T. Momoi, H. Sasaki, C. Yamanaka, T. Yorifuji and H. Mikawa, "Serum Copper and Zinc Levels in Epileptic Children with Valprate Treatment," Epilepsia, Vol. 33, No. 3, 1992, pp. 555-557. http://dx.doi.org/10.1111/j.1528-1157.1992.tb01709.x

[83] P. J. Barlow, P. E. Francois, I. J. Goldberg, I. Richardson, M. G. Izmeth, K. Kumpeson and P. Sykes, "Trace Metal Abnormalities in Long Stay Hyperactive Mentally Handicapped Children and Agitates Senile Dements," Journal of the Royal Society Medicine, Vol. 79, No. 10, 1986, pp. 581-583.

[84] A. Walsh, "The Application of Atomic Absorption Spectra to Chemical Analysis," Spectrochimica Acta, Vol. 7, 1956, pp.108-117.

[85] D. A. koog, F. J. Holler and T. A. Nieman, “A Prinicples of Instrumental Analysis," 5th Edition, Harcourt Brace \&
Company, Philadelphia, 1998.

[86] A. Verrotti, F. Basciani, D. Trotta, M. P. Pomilio, G. Morgese and F. Chiarelli, "Serum Copper Zinc Selenium Glutathione Peroxidase and Superoxide Dismutase Levels in Epileptic Children before and after 1 Year of Sodium Valproate and Carbamazepine Therapy," Epilepsy Research, Vol. 48, No. 1, 2002, pp. 71-75. http://dx.doi.org/10.1016/S0920-1211(01)00322-9

[87] F. Armutcu, E. Ozerol, A. Gruel, M. Kanter, H. Vural, C. Yakinci and O. Akyol, "Effect of Long-Term Therapy with Sodium Valproate on Nail and Serum Trace Element Status in Epileptic Children," Biological Trace Element Research, Vol. 102, No. 1-3, 2004, pp. pp. 1-10.

[88] A. Ilhan, E. Uz, S. Kali, A. Var and O. Akyol, "Serum and Hair Trace Element Levels in Patients with Epilepsy and Healthy Subjects: Does the Antiepileptic Therapy Affect the Element Concentrations of Hair," European Journal of Neurology, Vol. 6, No. 6, 1999, pp. 705-709. http://dx.doi.org/10.1046/j.1468-1331.1999.t01-1-660705 .

[89] S. Altunbasak, F. Biatmakoui, V. Baytok, O. Herguner, H. R. Burgut and L. Kayrin, "Serum and Hair Zinc Levels in Epileptic Children Taking Valprioic Acid," Biological Trace Element Research, Vol. 58, No. 1-2, 1997, pp. 117125. http://dx.doi.org/10.1007/BF02910672 